\section{UCDNN}

LIBRARY
University of Connecticut OpenCommons@UConn

Faculty Articles and Papers

School of Law

1992

\title{
The Question that Killed Critical Legal Studies
}

Michael Fischl

University of Connecticut School of Law

Follow this and additional works at: https://opencommons.uconn.edu/law_papers

Part of the Law and Philosophy Commons, and the Public Law and Legal Theory Commons

\section{Recommended Citation}

Fischl, Michael, "The Question that Killed Critical Legal Studies" (1992). Faculty Articles and Papers. 76.

https://opencommons.uconn.edu/law_papers/76 


\section{HEINONLINE}

Citation: 17 Law \& Soc. Inquiry 7791992

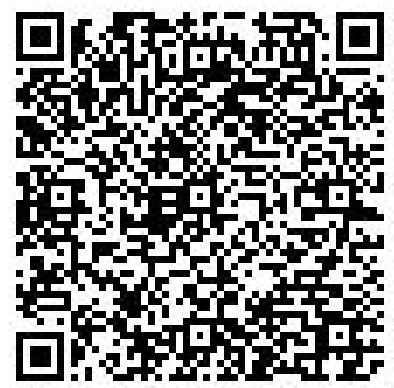

Content downloaded/printed from

HeinOnline (http://heinonline.org)

Mon Aug 15 16:52:23 2016

-- Your use of this HeinOnline PDF indicates your acceptance of HeinOnline's Terms and Conditions of the license agreement available at http://heinonline.org/HOL/License

-- The search text of this PDF is generated from uncorrected OCR text.

-- To obtain permission to use this article beyond the scope of your HeinOnline license, please use:

https://www.copyright.com/ccc/basicSearch.do?

\&operation $=$ go\&search Type $=0$

\&lastSearch $=$ simple\&all=on\&titleOrStdNo $=0897-6546$ 


\section{The Question That Killed Critical Legal Studies}

\section{Richard Michael Fischl}

Mark Kelman, A Guide to Critical Legal Studies. Cambridge, Mass.: Harvard University Press, 1987. Pp. 360. \$30.00.

A short while ago, I attended the 25th reunion of my eighth-grade graduation class. I had been looking forward to getting together with the 70 or so folks with whom I had experienced parochial school during the late 1950s and early 1960s for a host of reasons-not the least of which was that I expected to see my "first love," to whom I had not spoken in well over 20 years. I had long since blown that candle out, but I was intrigued by reports from mutual friends and acquaintances suggesting that she and I had followed remarkably parallel life paths. She, too, had gone to law school; she, too, had gone on to teaching after a stint in practice; she, too, had come to love the classroom and to enjoy scholarly life; and she, too, had evidently succumbed to the entreaties of her colleagues to undertake a multitude of thankless institutional-service tasks-the last a pattern of behavior that perhaps only unexpurgated Catholic guilt could explain. So I was dying to know: Did she still go to church? The Church? To confession? Did she take communion during the Eastertide? Eat meat on Fridays?

When the moment of truth at last arrived, she had a different agenda. "So," she said after a warm hello, "I hear you're a crit."' My mind raced for a response. I couldn't deny it-not, in any event, in this setting, where

Richard Michael Fischl is professor of law, University of Miami. The author extends his heartfelt thanks to Tony Alfieri, Terry Anderson, Jim Atleson, David Caploe, Marc Fajer, Duncan Kennedy, Jeremy Paul, Pierre Schlag, Steve Schnably, and Steve Winter for their thoughtful criticisms of an earlier draft.

1. All quotes are to the best of my recollection. Given the splendid reveries conjured up by the occasion-not to mention the beer I was drinking-I make no claims to complete accuracy. 
there was a serious possibility that even a single evasive maneuver might prompt a nearby cock to crow at dawn's first light. Besides, I suspected that she had a highly credible source: a classmate with whom we'd both kept in touch over the years, who is a disciple of the late Allan Bloom and has had a bit of a closed mind himself with respect to my longstanding association with critical legal studies. I opted instead for confession and avoidance, intended primarily to get us off the subject fast. "Relax," I replied, "We're no threat to anyone anymore. Greetings from the dustbin of history."

"It was bound to fail, Michael," she continued, in the patient and sympathetic tone that has no doubt helped make her the great teacher that by all accounts she has become. "The problem with critical legal studies is that it didn't offer any alternative program. Now I'm no great defender of the rule of law, but what would you put in its place?"

"If cls is dead," I replied, "that's the question that did us in." I didn't try to explain, and she didn't seem to mind. (Someone ought to write something about the ways in which the supposedly distinct rhetorical structures of cocktail banter and the Socratic method in some missing mirror meet). Mercifully, the conversation moved on to other and far more agreeable topics, and all of us to a truly remarkable weekend of rich reminiscence and powerful reconnection. ${ }^{2}$ But my classmate's question and the kernel of truth contained in my glib response have stuck with me since. This essay, then, is about that question-What would you put in its place? and the role that it has played in the reaction of many mainstream legal academics to the critical legal studies movement.

$$
* * * * *
$$

Truth be told, a number of close friends from within cls tried to convince me to select a different title for this piece, fearing that irony might be mistaken for eulogy - particularly among those who, for one reason or another, might not mourn for a moment the movement's passing. So let the record show that the rumors of our demise are greatly exaggerated: Having in many ways set the intellectual agenda for legal theory in the $1980 \mathrm{~s}^{3}$

2. For the record, her answers to my questions were: (church) no; (Church) no; (confession) no; (communion) no; (meat on Friday) no, nor on any other day. Careers were thus not all that we had in common.

3. See, e.g., "Constitutional Law from a Critical Legal Perspective: A Symposium," 36 Buff. L. Rev. 211 (1987); Symposium, "Roberto Unger's Politics: A Work in Constructive Social Theory," 81 Nw. U.L. Rev. 589 (1987); "Professing Law: A Colloquy on Critical Legal Studies," 31 St. Louis U.L.J. 1 (1986); "Symposium on Critical Legal Studies," 6 Cardozo L Rev. 691 (1985); Symposium: "A Critique of Rights," 62 Tex. L Rev. 1363 (1984); "Critical Legal Studies Symposium," 36 Stan. L. Rev. 1 (1984); Symposium, "The Public/ Private Distinction," 130 U. Pa. L Rev. 1289 (1982); Symposium, "Legal Scholarship: Its Nature and Purposes," 90 Yale LJ. 955 (1981); see also Duncan Kennedy \& Karl E. Klare, "A Bibliography of Critical Legal Studies," 94 Yale LJ. 461 (1985) (listing over 500 clsproduced or influenced books and articles published through the early $1980 \mathrm{~s}$ ). 
cls scholars and those working in kindred critical/progressive traditions are alive and well, rethinking old issues, ${ }^{4}$ exploring new ones, ${ }^{5}$ and doing what is for my money the most interesting and important work in legal scholarship today. ${ }^{6}$

But if the title is thus somewhat hyperbolic, it nevertheless captures something very real about the relationship between critical legal studies and the rest of the profession. By my estimate, the average non-cls academic will converse politely with a crit for about three minutes before asking-pointedly-some version of my eighth-grade classmate's question. Published reactions to and assessments of our work are scarcely more patient. Listen, for example, to the chorus of reviewers of Mark Kelman's A Guide to Critical Legal Studies as they endlessly repeat the same refrain:

Time after time, a reader wants to cry out: "Doubtless, it is all a mess. But what, exactly, do you propose to put in place of the legal system you are attacking?"?

Like much other CLS literature, Kelman's book is long on withering critiques of adversaries and short on positive prescriptions of alternate solutions. ${ }^{8}$

The critics Kelman summarizes have themselves been criticized for their negative approach. They have been challenged to come up with a theory to replace the theories that they have been so busy dismantling. ${ }^{9}$

Having seen through rationalism, but forsaken Western tradition, where can [cls scholars] turn for the content of their radical utopia? ... Kelman is not alone among Crits in his inability to articulate a concrete radical alternative. ${ }^{10}$

The crits have seemed unwilling to explain what kind of society they want, or what kind of social change they would like to see. ... The[y] have never tried seriously to propose concrete social changes; indeed,

4. See, e.g., the recent considerable refinement of earlier cls analyses of the recurring rhetorical structures of legal argument in Duncan Kennedy, "A Semiotics of Legal Argument," 42 Syracuse L Rev. 75 (1991); Jeremy Paul, "The Politics of Legal Semiotics," 69 Tex. L Rev. 1779 (1991); J. M. Balkin, "The Promise of Legal Semiotics," 69 Tex. L. Rev. 1831 (1991).

5. See, e.g., Symposium, "Beyond Critique: Law, Culture, and the Politics of Form," 69 Tex. L. Rev. 1595 (1991); "Postmodernism and Law: A Symposium," 62 U. Colo. L. Rev. 439 (1991); Symposium: "The Frontiers of Legal Thought" (pts. 1-3), 1990 Duke LJ. 193, 375,625 .

6. See generally David Kairys, ed., The Politics of Law: A Progressive Critique (rev. ed. New York: Pantheon, 1990) ("Kairys, Politics of Law").

7. Eugene D. Genovese, "Critical Legal Studies as Radical Politics and World View," 3 Yale J.L. \& Hum. 131, 133 (1991) (book review).

8. Theodore J. St. Antoine, Book Review, 43 Indus. E̊ Lab. Rel. Rev. 142, 142 (1989).

9. Robert E. Rodes, Jr., "Critical Legal Studies," 39 J. Legal Educ. 141, 141 (1989) (book review).

10. William B. Lindsey, "Well-plowed Fields," Nat'l Rev., 29 April 1988, at 47, 48. 
it is hard to imagine what they could propose that would not be essentially reformist. ${ }^{11}$

Kelman's first failure, then, is his inability to make a positive case for CLS by showing that CLS itself posits something other than destruction of the current legal order.... Why read a tedious summary of a movement's views when the movement will ultimately be judged as trendy and insubstantial for its lack of an alternative? Until CLS has a "coherent" legal model of its own, it does no one any lasting good to attack the current model as "incoherent." 12

[Kelman] finally asserts the central CLS story: We think in reified systems that make the social world seem necessary, natural[,] and just. . . But Kelman ... never gives an account of his payoff: how we could remake the world. ${ }^{13}$

Mr. Kelman believes that if he can demolish (or as he likes to say, "trash") the intellectual foundations of Western liberalism as they are revealed in the writings of mainstream jurists, something better will rise from the ashes, but he makes no effort to justify that faith, instead ending the book with this wistful sentence: "[Critical scholars] try to retrace, hoping to see where we first got lost."14

For there to be significance in these criticisms [of liberalism] it is essential that Kelman establish both that there is some escape from the incoherence he sees and that there is a moral or practical failure of the liberal world he describes. ... Even if CLS criticisms are meaningful, there is no alternative vision described in anything other than the most general and abstract of terms. ${ }^{15}$

Nor is this phenomenon confined to a narrow span of the political spectrum; as these quotations suggest, What would you put in its place?-or some closely related variant of that question-is with striking regularity posed by individuals associated with the academy's ideological left, right, and center alike.

My argument here is that this question-not the supposed failure of cls to answer it, but the assumptions and structures of thought that are embedded in and revealed by the question itself-has been a principal cause of a systematic misreading and mischaracterization of cls work by mainstream legal scholars. This essay is thus a continuation of the project begun by Pierre Schlag, Richard Delgado, and my colleague Steve Winter in

11. Daniel Farber, "Down by Law," New Republic, 4 Jan. 1988, at 36, 39.

12. Richard L. Barnes, "Searching for Answers without the Questions," 34 S.D.L. Rev. 220, 221, 222 (1989) (book review).

13. John Stick, "Charting the Development of Critical Legal Studies," 88 Colum. $L$. Rev. 407, 432 (1988) (book review). 23.

14. Richard A. Posner, "A Manifesto for Legal Renegades," Wall St. J., 27 Jan. 1988, at review).

15. Calvin R. Massey, "Law's Inferno," 39 Hastings LJ. 1269, 1271 (1988) (book 
their recent symposium, "The Critique of Normativity."16 Schlag and his confreres posit something of a Heisenberg uncertainty principle operating in the rhetorical structures of American legal thought: The obsessive focus on normative questions-Where should we go? What should we do? What would you put in its place?-makes it all but impossible for legal scholars to comprehend the current predicament of law and legal theory, to see where we already are and to recognize what we already do. ${ }^{17} \mathrm{My}$ aim here is to examine further the role that normativity plays in producing legal thought's considerable capacity for resisting self-reflection and analysis. To paraphrase a sage dictum, those who view the world through the lens of the normative question have a tendency to see normativity even when it isn't there. They have thus frequently misunderstood the work of scholars who are, or at least who endeavor to be, relentlessly critical-who are doing work that is designed to cultivate the very self-consciousness that mainstream legal thought so mightily resists. Indeed, the argument here is that this obsession with normativity has distorted the mainstream understanding of critical scholarship in a particular and systematic way, leading many readers to conclude that the refusal of cls scholars to engage the What would you put in its place? question is at best an irresponsible act of naive utopianism, and at worst a strategic move designed to hide a covert commitment to some sort of Stalinist totalitarianism.

16. 139 U. Pa. L. Rev. 801 (1991).

17. See Pierre Schlag, "Normativity and the Politics of Form," 139 U. Pa. L. Rev. 801, 804-5 (1991) (footnote omitted):

What should be done? How should we live? What should the law be? These are the hard questions. These are the momentous questions.

And they are the wrong ones.

They are wrong because it is these very normative questions that reprieve legal thinkers from recognizing the extent to which the cherished "ideals" of legal academic thought are implicated in the reproduction and maintenance of precisely those ugly "realities" of legal practice the academy so routinely condemns. It is these normative questions that allow legal thinkers to shield themselves from the recognition that their work product consists largely of the reproduction of rhetorical structures by which human beings can be coerced into achieving ends of dubious social origin and implication. It is these very normative questions that allow legal academics to continue to address (rather lamely) bureaucratic power structures as if they were rational, morally competent, individual humanist subjects. It is these very normative questions that allow legal thinkers to assume blithely that -in a world ruled by HMOs, personnel policies, standard operating procedures, performance requirements, standard work incentives, and productivity monitoring - they somehow have escaped the bureaucratic power games. It is these normative questions that enable them to represent themselves as whole and intact, as self-directing individual liberal humanist subjects at once rational, morally competent, and in control of their own situations, the captain of their own ships, the Hercules of their own empires, the author of their own texts.

It isn't so.

Schlag laid the groundwork for this provocative thesis in " 'Le Hors de Texte, C'est Moi': The Politics of Form and the Domestication of Deconstruction," 11 Cardozo L. Rev. 1631 (1990), and "Normative and Nowhere to Go," 43 Stan. L. Rev. 167 (1990); he further elaborated it in "The Problem of the Subject," 69 Tex. L Rev. 1627 (1991). 
In order to provide a convincing account of what I see as the underlying conceptual phenomenon, it seems sensible to begin the essay with an extended example of the sort of misreading of cls to which I am referring. To that end, I have chosen the review of Kelman's Guide written by Professor Calvin Massey (hereafter MR), ${ }^{18}$ one of the voices in the What would you put in its place? chorus we heard from a moment ago. A word or two about the adequacy of representation provided by the texts in question is thus in order. First, I make no claim that Massey is a "typical" legal academic, whatever that means; though he is evidently a productive and talented scholar, ${ }^{19}$ the review under examination suggests an attraction to "natural law" theory that is still relatively unusual in the legal academy (MR at 1292-94). Nor, for that matter, do I mean to suggest that Kelman's Guide is in any sense the "quintessential" cls work. For one thing, it was published in 1987, toward the end of what may well have been the halcyon days of $\mathrm{cls} ;{ }^{20}$ it is therefore to some extent already outdated. Indeed, at least in part for that reason, the Guide gives the shortest shrift to several strands of cls scholarship-including critical race theory and deconstruction-that seem to me to be central to the cls contribution to legal thought. Moreover, some of the difficulties that Massey and other reviewers have evidently encountered in understanding the book may be at least in part attributable to its particular author rather than common to cls work generally-a point to which I will return shortly. Nevertheless, the Guide remains the single most ambitious and comprehensive attempt to date to describe the contours of cls as an intellectual movement; ${ }^{21}$ similarly, Massey's review is by far the most sustained critical analysis of the Guide written by anyone outside of cls. Taken together, they offer an opportunity to observe in some detail-quote by quote and citation by citation-the anatomy of a misreading of cls work.

Part I of the essay, then, is a close look at Kelman's presentation of several classic cls arguments and the sometimes striking, sometimes subtle misunderstandings of those arguments offered by Massey. In part II, I attempt to demonstrate that Massey's misreading is in large part a product of a pattern of unexamined assumptions that are central to normative legal thought. In part III, I will attempt to demonstrate that this phenomenon

18. 39 Hastings LJ. 1269.

19. An Infocheck run reveals that Massey published over a dozen law review articles between 1986 and 1992, and that many of them appeared in such distinguished journals as the University of Chicago Law Review, Wisconsin Law Review, Duke Law Joumal, and his home institution's Hastings Law Joumal.

20. And Halcion nights, if my own experience as a crit securing tenure at the time in question is any indication.

21. Despite its title, Roberto Mangabeira Unger's The Critical Legal Studies Movement (Cambridge, Mass.: Harvard University Press, 1986) represents much more of an effort to construct and massage the author's own provocative jurisprudential and social theories than it does an attempt-like the one Kelman provides in the Guide-to synthesize and analyze the work of the cls movement as a whole. 
is at work in the critiques of cls by a wide range of non-cls academics. To that end, we shall consider the reviews of the Guide written by Richard Barnes, a seemingly moderate conservative; Daniel Farber, a centrist-liberal pragmatist; and Eugene Genovese, an eminent Marxist historian. My argument is that each of these writers has misunderstood-and accordingly mischaracterized—cls work in much the same way as Massey has and that What would you put in its place? thinking is the common culprit.

\section{MISSING THE MARK}

\section{A. Kelman and the Privileged Positions}

Much of the Guide is an exploration of what Kelman and others in cls have called the contradictions of liberal legal thought-the "mirror-image contradictory norms" (at 13) that frame our recurring debates with respect to the appropriate form of legal commands (bright-line rules vs. situationsensitive standards) (ch. 1); the nature of values (subjectivism vs. objectivism) (ch. 2); the foundations of our behavior (intentionalism vs. determinism) (ch. 3); and, to some extent underlying the rest, the idealized forms of human association (individualism vs. altruism) (at, e.g., 4-5, 54-63). The result, according to Kelman, is "justificatory indeterminacy": the simultaneous commitment of the legal system to these competing norms, "each of which dictates the opposite result in any case (no matter how 'easy' the case first appears)" (at 13). One of the great strengths of the Guide is that Kelman extends the descriptive power of this analysis considerably by attempting to vindicate the intuition that liberalism systematically favors one of the two poles in each of the contradictions - that rules, intentionalism, subjectivity of value, and individualism are "privileged positions" in liberal legal thought, and that the countervailing commitments to standards, determinism, objectivism, and altruism are to a considerable degree devalued and even repressed (at, e.g., 3-4, 290-95). Taken together, Kelman observes, these privileged positions "describe the program of a remarkably right-wing, quasilibertarian order" (at 4-5).

As the rest of this essay will attempt to demonstrate, Kelman's vigorous analysis and criticism of liberalism's "privileged positions" apparently convinced many of his reviewers that cls supports a counterprogram of unrelenting legal informality and communitarianism, firmly founded on a determinist view of human nature and a belief in the existence of objective values. I think that this is a misconstruction of Kelman, and it certainly is of most of cls; exposing and indicting the "privileged positions" is not the same thing as holding the starry-eyed view that an amalgam of their oppo- 
sites would constitute some sort of cls-inspired Utopia. ${ }^{22}$ Indeed, to take just one example, if liberalism's available image of autonomy as an ideal projects a world that only a robot could love, ${ }^{23}$ its vision of community is frequently naive and sentimental;24 and the relevance of either image to current experience is awfully difficult to discern. ${ }^{25}$ Accordingly, we reserve our harshest criticisms for individualism, rules, etc., because they are privileged, not because we think that their devalued companions form a preferable alternative in anything like their present form. ${ }^{26}$

$$
* * * * *
$$

Yet it is only fair to note that there is a textual basis for a different reading of the Guide. For one thing, Kelman abruptly dismisses the insights of deconstruction and linguistic theory (at 12-14 \& n.27), a move that ultimately leaves him without a convincing account of the privileging

22. See, e.g., Roberto Mangabeira Unger, Knowledge and Politics 7 (New York: Free Press, 1975) ("one can begin to imagine the rudiments of a better alternative to the liberal doctrine, but this alternative should not be mistaken for the liberal view set upside down").

23. And a male robot at that. See, e.g., Mari J. Matsuda, "Liberal Jurisprudence and Abstracted Visions of Human Nature: A Feminist Critique of Rawls' Theory of Justice," 16 N.M.L. Rev. 613 (1986); Catharine A. MacKinnon, Toward a Feminist Theory of the State 162-63 \& n.30 (Cambridge, Mass.: Harvard University Press, 1989). (1988).

24. See, e.g., Robin West, "Jurisprudence and Gender," 55 U. Chi. L. Rev. 1, 28-36

25. See Schlag, 139 U. Pa. L. Rev. at 907:

What the liberals fail to notice is that while they are talking about the individual versus community, the reproduction and extension of bureaucratic practices routinely traverses back and forth across the public/private distinction without giving that venerable liberal distinction a moment's thought-thereby extinguishing ab initio the liberal version of both individualism and community. It turns out that being a liberal means that you worry a great deal about getting just the right combination of individual freedom and community, while getting neither.

26. For this reason, it has always seemed to me that in the debate over the critique of rights the critical race theorists were the "true" crits, providing thick and nuanced descriptions of profound conflict in the social experience of law and challenging the comparatively arid analyses of both liberal rights and left "anti-rights" thinkers. See, e.g., Richard Delgado, "The Ethereal Scholar: Does Critical Legal Studies Have What Minorities Want?" 22 Harv. C.R.-C.L. L. Rev. 301, 314-18, 321 (1987); Mari J. Matsuda, "Looking to the Bottom: Critical Legal Studies and Reparations," 22 Harv. C.R.-C.L. L. Rev. 323, 332-42 (1987); Patricia J. Williams, "Alchemical Notes: Reconstructing Ideals from Deconstructed Rights," 22 Harv. C.R.-C.L L Rev. 401, 404-6 (1987). Indeed, I had thought that this was pretty much the point of that marvelous passage from E. P. Thompson's Whigs and Hunters: The Origins of the Black Act (New York: Pantheon Books, 1975) cited so frequently in the first generation of cls work:

[T] he rule of law itself, the imposing of effective inhibitions upon power and the defense of the citizen from power's all-intrusive claims, seems to me to be an unqualified human good. To deny or belittle this good is, in this dangerous century when the resources and pretensions of power continue to enlarge, a desperate error of intellectual abstraction. More than this, it is a self-fulfilling error, which encourages us to give up the struggle against bad laws and class-bound procedures, and to disarm ourselves before power. It is to throw away a whole inheritance of struggle about law, and within the forms of law, whose continuity can never be fractured without bringing men and women into immediate danger.

Id. at 266 (emphasis in original). 
phenomenon he otherwise so perceptively unearths and criticizes. The reader might thus form the impression that privileging is simply a result of bias, design, or intellectual infirmity on the part of argument choosersfolks picking the wrong poles, as it were-rather than a product of widely shared but unexamined structures of thought revealed and reinforced by the linguistic practices that Kelman's account all but ignores. ${ }^{27}$

Indeed, that impression is reinforced by some of Kelman's attempts at irony: "Rules," he declares at the end of the first chapter, "are the opiate of the masses" (at 63). Standards, he might just as well have added, are the apologetic mush of the liberal intelligentsia-as any crit who has taught her way through the Second Restatement of Contracts (to take just one example) would be quick to point out. ${ }^{28}$ Instead, Kelman waxes romantic about the connection between standards and a commitment to the possibility of moral consensus and discourse, offering short shrift to what are by now the conventional counterarguments that in any other circumstance cls would be the first to deploy (at 59-63). A fair reading of the Guide as a whole-and of critical scholarship more generally-makes it clear that cls is far more anti-"rule" than it is pro-"standard." But it is no wonder that some readers-Professor Massey among them-might be prompted by Kelman's radical-chic sloganeering to conclude that Kelman and other cls scholars would prefer "an exclusiviely standard-based legal system" (MR at 1275 ) and thus condemn bright-line rules as "politically incorrect" (id. at 1274).

The Guide may invite this sort of misreading in a second way. Early in the book, Kelman articulates the keen insight (at 4-5, emphasis in original) that:

liberalism is culturally and intellectually self-confident only in its right-wing libertarian form, because libertarianism is in one sense sim-

27. To be sure, Kelman seems to be aware of a linguistic dimension to the privileging phenomenon, observing at one point that "[r]ule -exception relations [such as contract law's treatment of paternalist interventions as begrudging exceptions to a general rule of private ordering] are communicated by subtle linguistic hints" (at 292). Yet the way Kelman frames this point suggests that he thinks that privileging exists apart from and prior to the linguistic structures it is then "communicated" through. Indeed, he reveals a similar assumption in his account of legal indeterminacy, a phenomenon he attributes to conflicts within liberalism's underlying conceptual or "justificatory" premises rather than to the recurring analytical structures of legal texts (at 12-13). For analyses that by contrast treat thought and language as interpenetrating, see, e.g., Schlag, 11 Cardozo L. Rev. 1631 (cited in note 17); Steven L. Winter, "Transcendental Nonsense, Metaphoric Reasoning, and the Cognitive Stakes for Law," 137 U. Pa. L. Rev. 1105 (1989).

28. See, e.g., Schlag, 139 U. Pa. L Rev. at 931 n.32 (cited in note 17):

Sometime in the future, the ALI will publish the Third Restatement on Everything. It will be a comprehensive compilation of four-part balancing tests all based on key terms that will themselves be defined in terms of four-part balancing tests, and so on in such a way that the Third Restatement on Everything will have achieved the first totally comprehensive, totally closed system of totally self-referential four-part balancing tests. It will be great. Then it will turn to mud. 
ply the summary of the privileged positions in liberal thought. My strong belief is that people who call themselves liberals can most comfortably explain their attachment to a society based on the privileged poles ... , but that they are remarkably inarticulate and uncomfortable explaining their often powerful nonlibertarian impulses.

This is Kelman at his cls best: the astute observer of the subtle relationship between style and substance in legal argument, identifying a particular intellectual phenomenon reproduced broadly across our legal culture. ${ }^{29}$ But from that provocative observation he appears to conclude not just that liberalism is most self-confident in its right-wing libertarian form but that this is what liberalism really is. Law and economics, he argues, "is the best worked-out, most consummated liberal legal ideology of the sort that CLS has tried both to understand and to critique" (at 114); and, true to his word, Kelman spends much of the rest of the book claiming to challenge liberal legalism but doing battle instead with the right-wing legal economists (at, e.g., 114-85).

We've seen this move before: Rather than challenging the positions that you've actually taken, the critic outlines something he insists is the "best worked-out, most consummated" version of your theory-never mind that you've spent a very great deal of scholarly time and effort challenging that supposedly "best worked-out, most consummated" version yourself. Those of us associated with cls think it grossly unjust when our critics make an analytically identical move and argue that Stalinist totalitarianism is the "best worked-out, most consummated" version of our position-in the face of the fact that a common intellectual thread that ties together virtually all cls work is its rejection of the authoritarianism and vulgar determinism suggested by the Stalinist label. To be sure, in the context of our culture a charge of closet libertarianism carries with it none of the insidious political baggage that accompanies a charge of Stalinism. But by deploying the argumentative strategy of judging the merits of an idea by the way it would look if taken to its supposed logical extreme-and in effect accusing others of taking positions that they in fact conscientiously reject ${ }^{30}$-Kelman invites his readers to do the same with his own

29. Of perhaps even greater significance is his related observation that critical scholars "find themselves in roughly the same relationship to their actual political beliefs as left liberals are to theirs. That is, they have ... learned to argue confidently for a position one step to the right of their actual position" (at 5, emphasis in original). I think that Kelman is right in this, but I do wish that he had elaborated the point, for it may well be the most interesting and powerful example of just how "privileged" the so-called privileged positions are: Even those of us who are more or less conscious and in any event critical of the privileging are nonetheless caught in the gravitational pull. Here too Kelman's account might have been enriched by the insights of deconstruction and language theory that he so summarily dismisses.

30. See, e.g., the thoughtful critique of law and economics in Ronald Dworkin, Law's Empire 276-312 (Cambridge, Mass.: Harvard University Press, Belknap Press, 1986). 
arguments. As will shortly be evident, that invitation produces many enthusiastic takers. ${ }^{31}$

\section{B. Massey's Review}

Having said all that, the misreadings of the Guide are not in my view all nor even mostly Kelman's fault. I turn, then, to two extended illustrations of my point drawn from Massey's review: the first, his claims regarding the cls "position" on choice, determinism, and paternalism; the second, his claims regarding cls views on the relationship between law and society.

\section{Choice, Determinism, and Paternalism ${ }^{32}$}

According to Massey, "[t]he CLS vision is of a world where choice is illusory, where we are all determined by extrinsic factors" (MR at 1294) and where "the nominal 'self' that appears to choose"-in the course of private contracting, for example- "is utterly determined by its social framework" (id. at 1281). Accordingly, says Massey quoting the Guide, Kelman and cls think that "the answer is simply "[c]ollectively imposed uniformity ... [which] may well be needed to rationalize a choice that few can make unless it seems utterly out of their hands, even though they would in some sense like to make it" " (id. at 1280). "Naturally," Massey continues, "it is the CLS vision of the appropriate choice that must be collectively imposed, for Kelman senses that there might be some resistance to the choices mandated for Montana cowboys by a mandarin class of elite academic radicals" (id.). This " 'paternalistic' substitution of new choices," argues Massey, is in the view of cls "really just a way of making

31. I doubt very much that any of this was intentional on Kelman's part. Rather, I suspect that he was just playing to his strengths, for what Kelman does best-and better than just about anyone else-is to challenge the legal economists on their own turf. Indeed, Kelman's basic insight - that liberal culture is most secure in defending the libertarian version of its world view-exposes a stark vulnerability of liberal thought: Undermine legal economics, and you may well have taken its queen. For one thing, the claims of the legal economists seem in a remarkable number of ways to vindicate what passes for "common sense" among the educated laity; establishing that those claims already assume many of the very "commonsense" propositions that they purport to prove is accordingly a sound strategy in the battle for the hearts and minds of our students and of the legal profession generally. Moreover, in much the same way that the Realist critique dramatically changed the parameters of academic debate-less perhaps because "we are all Realists now" than because virtually no one who admits to being a formalist will be taken seriously-the work of Kelman, Duncan Kennedy, Pierre Schlag, and others has succeeded in demonstrating that Coase cuts both ways and that price theory is to social life pretty much as Velveeta is to cheese.

32. Unless otherwise indicated, all ellipses, bracketed material, and emphases appear here just as they did in Massey's review. 
an individual's preferences conform to his 'true' self" (id. at 1281). Indeed, Massey asserts, Kelman ultimately "dismisses" doubts about the legitimacy of even those paternalist interventions that cannot be justified on " "true' self" grounds and "insists that 'it is ultimately neither possible nor desirable for [cls] to disclaim the legitimacy of paternalist motives" (id. at 1280-81). Massey reports that Kelman attempts to "justify" such paternalism on the ground that it is "a pervasive activity" in which "even liberals engage"; but "[g]iven the fear and loathing with which the Crits approach liberal thought and practice," Massey reasons, "this is a surprising justification" (id. at 1281).

In point of fact, Kelman's arguments about the insights of cls scholarship regarding choice, determinism, and paternalism bear not the slightest resemblance to Massey's characterizations. In the passages to which Massey refers, Kelman's focus is on liberalism's simultaneous commitment to conflicting images of the individual-one in which desires are the unmediated product of free will versus one in which they are determined by the various forces of social life-not on the supposed exclusive belief of cls scholars in one image or the other (at 126-41; see also 86-113). Kelman is not, as Massey would have it, arguing that "choice is illusory" (MR at 1294) and promoting a regime of cls-imposed "paternalism" in its place (id. at 1280-81). Rather, Kelman is challenging the rigid intentionalist view of those who contend that individual preferences-even self-endangering ones-are "contingent only on factors far beyond our conscious collective control" (at 135). Kelman points to a host of examples drawn from legal life that strongly suggest that the converse is the case (or at least that we often act as if we believe that it were)-citing, for example, mandatory "waiting periods" for certain kinds of purchases, the rules regulating the right to refuse extraordinary medical care, and abortion statutes requiring parental notification (at 133-34 \& nn.60-63). Obviously, the deployment of each of these devices assumes that individual preferences can change and, more to the point, that the context in which choice takes place may in some significant sense "determine" the outcome.

Kelman, then, is simply recounting the important cls insight that liberal legalism is already rife with paternalism, but that it often represses this fact by reconstructing the individual in a determinist image and asserting that legal decision makers are merely vindicating the (reconstructed) individual's "true" or "considered" preferences rather than overruling them (at 137, emphasis in original):

Given the availability of a determinist picture of the self, it is not surprising that there is no clear line between paternalistic interventions that avowedly disrespect a chooser's will and appeals to the individual's own preference structure. If some hypothetical self significantly distinct from the concrete person we encounter, "created" by 
a different social framework, is always imaginable, we can always claim to appeal not to "true" judgments of the good but to this hypothetical self's judgments of the good.

This is a classic cls move: trumping the privileged position (here, intentionalism) on its own turf by reaching into the lawyer's bag of tricks for a stock argument provided by the corresponding liberal counterimage (here, determinism). ${ }^{33}$ But pointing to the "availability" within liberalism of "a determinist picture of the self" that lawyers, judges, and academics can and regularly do use to justify paternalistic state interventions is something rather different from making the argument that Massey wrongly attributes to Kelman-that cls scholars actually believe that such interventions are "really just a way of making an individual's preferences conform to his 'true' self" (MR at 1281).

Let us carefully consider Massey's related claim that Kelman and other cls scholars- who have identified the various difficulties we encounter in attempting to distinguish in any meaningful way the individual's "true" or "considered" preferences from ambivalence, whim, or the exogenous effects of decisional context (at 127-37)—think that "the answer is simply '[c]ollectively imposed uniformity ... [which] may well be needed to rationalize a choice that few can make unless it seems utterly out of their hands, even though they would in some sense like to make it" (MR at 1280). Cast in that form, the position sounds a lot like a plea for a centrally planned, state-controlled economy with cls operating as the Central Committee; the reader would be unlikely to guess that in the passage to which Massey refers Kelman is talking about seat-belt laws and workplace safety legislation (at 135-36). Far from broadly embracing "[c]ollectively imposed uniformity" (MR at 1280), Kelman is once again analyzing the instances of that activity that already occur-once again demonstrating the availability of determinist imagery, and hence the legitimacy of certain paternalist interventions, within liberal legalism. And far from enthusiastically embracing that imagery as his own-let alone, as Massey claims, contending that cls should "impos[e]" its "vision" on "Montana cowboys" (id.)-Kelman expresses strong reservations about any claim that our interventions will actually influence individual preferences in the intended manner. ${ }^{34}$ Indeed, he issues a thoughtful warning to traditional

33. Notice, however, that the privileged position is challenged on its own rhetorical turf: Determinism is deployed in the service of a kinder, gentler free will. That's why we call it privileged.

34. One cannot help but notice that some of the more outspoken critics of cls reveal an endearing if somewhat boyish fascination with "cowboys" that is quite nearly as intense (and boyish) as their fixation with the cars crits supposedly drive. Compare $M R$ at 1281 (cowboys) and James D. Gordon III, "Law Review and the Modern Mind," 33 Ariz. L. Rev. 265, 269 (1991) (cars), with Brian Timmons, "That's No Okie, That's My Torts Professor," Wall St. J., 3 Apr. 1990, at $\$$ A, p. 20 (cowboys and cars). 
leftists who might be seduced by the temptations of knee-jerk statism (at 136-37, emphases in original):

Whether these collective efforts have in fact solidified or rendered less ambivalent many people's commitment to the aspects of character they may well have sought to strengthen is certainly as problematic and hopelessly contestable a contention as the claim that prohibitions on the manifestation of unwanted character traits (like racism or excessive risk taking) ultimately affect the character trait itself. . . Clearly, those of us committed to radical politics must be particularly sensitive to the possibility that our suppositions about how we will respond to our efforts to transform the world that frames us are urong, that our dreams simply won't take. It seems to me that it is vital to be sensitive to the resistance we may see to our efforts to change tastes.

To the extent that Kelman's analysis here is programmatic at all, then, he is contending rather plausibly that our efforts would be better focused on developing greater "sensitiv[ity]" to the resistance of those whose tastes we might attempt to change with any paternalist intervention, rather than on continuing the endless quest for trump cards in the essentially ideological debate over our "capacity to make correct ex ante decisions about human malleability" (at 137). But his principal point is that the liberal legalists embrace determinism and paternalism in spite of their rhetorical commitment to intentionalism and that they do so far more often than mainstream analyses have generally supposed (at 127-37).

$$
* * * * *
$$

In the discussion thus far, we have been focusing on Massey's characterizations of Kelman's claims regarding what might be called "soft paternalism"-that is, collective interventions that are justified as efforts to vindicate the "true" or "considered" preferences of individuals. I turn now to the question of "hard paternalism": the forthright overruling of individual choices, however "true" or "considered" they might be thought to be. Once again, Massey completely misunderstands Kelman's arguments.

Thus, far from "dismissing" doubts about the propriety of hard paternalism - as Massey would have it (MR at 1281) - Kelman expresses virtually nothing but doubts about it, doubts of his own and of cls scholars more generally. Noting that most cls scholars seem to be considerably more comfortable with the more modest claims of soft paternalism, Kelman first wonders whether this might be a "cowardly concession to the power of the liberal choice-satisfying paradigm" and the traditional association of paternalism "with nonliberal beliefs in false and true conscious- 
ness, objective good, [and] vanguard classes" (at 138). ${ }^{35}$ Alternatively, he suggests (at 138), cls scholars may have

run away from traditional paternalist analysis not simply because of its left-totalitarian Stalinist pedigree but also because of its right-elitist-racist-sexist pedigree (in which white male Anglo-Saxons forever describe women and people of color as incapable of knowing their own true interests, in need of the protection of the literal or figurative father).

As for Kelman's own views on hard paternalism, Massey is simply wrong when he says that Kelman "insists that 'it is ultimately neither possible nor desirable for [cls] to disclaim the legitimacy of paternalist motives' "( $M R$ at 1281). In fact, Kelman is once again attempting to demonstrate the extent to which paternalism-in even its hard version-is already a pervasive if often un- or underacknowledged norm. (In contract law, to take a field with which I am familiar, there is not just the obvious case of the doctrine of incapacity cited by Massey (id.), but also among many other examples those aspects of consideration doctrine that complicate the enforcement of unbargained-for promises in a multitude of social as well as commercial settings. ${ }^{36}$ ) "[O]nce one recognizes how unexceptional the activity we often try to exceptionalize and isolate really is," observes Kelman, it is "neither possible nor desirable for [cls] to disclaim the legitimacy of paternalist motives entirely" (at 138, emphasis added to show Massey's deletion). I need hardly point out that a claim that paternalist motives ought not to be discounted "entirely" is rather different from the suggestion contained in Massey's selectively edited version that paternalism should not be "disclaim[ed]" at all (MR at 1281, omitting without ellipses the word "entirely"). ${ }^{37}$ Indeed, Kelman presents an extended

35. To be fair to Massey, Kelman's decision to put the point this way is another example of how his tone may obscure the substance of his arguments-although a careful reading of the entire passage in question (at 138-41) suggests that this is another attempt at irony and, in any event, makes clear that Kelman himself shares many of these apprehensions about hard paternalism. From my own perspective, a far greater difficulty with Kelman's argument here is that he missed yet another opportunity to explore the privileged positions at work, this time by assuming that the rejection of paternalism by other cls scholars is the result of a conscious choice-"cowardly" or otherwise-rather than of an unreflective response to the privileging of decisional autonomy in liberal thought; indeed, perhaps Kelman's assumption of a conscious choice is itself simply another example of the privileging of intentionalism.

36. See, e.g., Mills v. Wyman, 3 Pick. 207 (Mass. 1825); see generally Duncan Kennedy, "Distributive and Paternalist Motives in Contract and Tort Law, with Special Reference to Compulsory Terms and Unequal Bargaining Power," 41 Md. L Rev. 563, 631-38 (1982) (collecting other examples from American contract law).

37. This is not the only place in Massey's review where his editing of Kelman's arguments may mislead. Consider Massey's claim (id. at 1284-85) that Kelman contradicts himself when he "castigates both CLS and mainstream scholars for assuming that norms have 'cross-culturally constant meaning' (p. 234) while he berates the constitutional framers as 'not an especially attractive group of people ...., but rather . . . overtly racist ... privileged 
analysis of the only sustained defense of hard paternalism in cls literature, Duncan Kennedy's 1982 piece in Maryland Law Review. ${ }^{38}$ And though he is generally sympathetic with Kennedy's effort, Kelman is nevertheless quite skeptical about the possibility of translating Kennedy's thoughtful insights about our interventions in the lives of persons we know well and care about deeply, to the more complex problem of "making decisions for faceless others" that we are obliged to confront in most legal contexts (at 138-41).

Massey grudgingly acknowledges that "even Kelman has difficulty accepting [Kennedy's argument] as a justificatory norm" for hard paternalism, but takes Kelman to task for the latter's purported attempt to "justify" the activity on the alternative ground of its "pervasive[ness]" in the very "liberal thought and practice" that cls is supposed to "fear and loath[e]" (MR at 1281). Massey misses the point, but he does so here in a manner that goes a long way to suggest the underlying basis for each of the misreadings we have thus far discussed: Massey is confusing normative argument with critical analysis. Thus, the bulk of Kelman's discussion is not an effort to "justify" paternalism by reference to some independent clsapproved normative criteria, any more than it is an attempt to defend a "vision ... of a world ... where we are all determined by extrinsic factors" (id. at 1294). Rather, it is an assault on the rhetorical hegemony of the privileged positions of intentionalism and choice-an attempt "to make the critical cases seem less exceptional" (at 133) by showing the ways in which liberal legalism repeatedly embraces determinism and paternalism, all the while denying that it is doing so.

\section{Law, Society, and Democracy}

Massey makes precisely the same mistake-confusing programmatic normativity with critique-when he attempts to characterize the views of

white males' " (p. 221). The ellipses are all Massey's, but it's worth noting exactly what he left out. What Kelman actually said was that the framers were an "overtly racist, slaveholding or slavery-tolerating group of privileged white males" (at 221, emphasis added to show Massey's deletion). Remove the italicized material, and Kelman sounds like a "typical" radical making wild and unsubstantiated charges; leave it in, and the passage reminds us of certain inconvenient but indisputable facts regarding our national heritage. See, e.g., U.S. Const. art. $1, \$ 2$ (requiring apportionment of representatives and taxes among the states to be calculated by reference to "the whole Number of free Persons . . . [and] three fifths of all other Persons"). Moreover, the content of the first excision reveals that Kelman was not, as Massey contends, judging the framers against "cross-cultura[l]" standards, but was instead challenging the "jurisprudence of original intention" and therefore questioning the utility of adherence to the framers' values in our oun times. Thus, Kelman's claim-which is completely consistent with his skepticism concerning "cross-cultura[l]" standards-is simply that the framers "are not an especially attractive group of people [and here is what Massey left out] to use as models" for solving contemporary constitutional problems (at 221, emphasis added).

38. 41 Md. L. Rev. 563. 
Kelman and cls regarding the relationship between law and society. Thus, Massey asserts that Kelman and other cls scholars believe that "law simply masks as natural or legitimate an oppressive social order that serves the interests of the ruling elite and that is culturally and historically determined" (MR at 1270 n.3; see also id. at 1287 n.39). Massey offers an example evidently designed to show that the "ruling elite," in the cls view, is engaged in the business of "oppressi[on]" even when it appears not to be; thus, according to Massey, "Kelman thinks the abortion liberalization wrought by Roe v. Wade, 410 U.S. 113 (1973), 'may have been responsive primarily to the demands . . . of men who wanted to strip women of a major socially functional barrier (fear of pregnancy) to men's demands for sexual access" "(MR at 1270 n.2). Pointing to the Guide's critique of the Legal Process theories generally associated with Hart and Sacks (at ch. 6), Massey accuses Kelman of viewing "the legislature" as "essentially a collection of racist, elitist, venal stooges of the dominant economic elite" ( $M R$ at 1283). Indeed, according to Massey, Kelman "dismisses democratic process (the electoral system is 'simply ... a blinding deflection')" and "thinks distinctions between courts and legislatures wholly irrelevant" (id. at 1281). "Presumably," Massey reasons-echoing his earlier claims about the supposed cls desire to "mandate" personal and contractual choices for "Montana cowboys" (id. at 1280)—in public life as well "the dictatorship of an enlightened elite in a utopian post-liberal world is the answer served up by CLS" (id. at 1281-82).

Once again, Massey's characterizations bear not the slightest resemblance to Kelman's arguments or to the claims of the cls scholarship generally. In the first place, far from contending that "law simply masks as natural or legitimate an oppressive social order that serves the interests of the ruling elite and that is culturally and historically determined" (MR at 1270 n.3), Kelman spends the better part of two chapters attempting to distance cls from such unreflective functionalist views; indeed, Kelman explicitly rejects claims that law does anything "simply" and denies that expressions like "serves the interests of the ruling elite" and "historically determined" represent meaningful concepts, let alone useful ways of understanding the rich and complex relationship between law and society (chs. 7-8).

Kelman's argument begins with cls elaborations of several traditional critiques of functionalism (at 244-53). Citing cls and other studies that "demonstrate that apparently similar social conditions have generated disparate legal responses, both cross-culturally and within the same culture" (at 245-46 \& nn.13-16) -as well as works that remind us of the vast chasm that may frequently lie between the law on the books and the law in practice (at 246 \& nn.17-19)—Kelman notes our nigh complete inability to identify with any regularity or precision either the legal reactions to 
which particular social conditions ostensibly give rise or, conversely, the legal causes that are supposed to bring about social change. Moreover, Kelman identifies cls work that vigorously challenges both the general functionalist assumption that "the direction of causality [in the development of law] is wholly from private desire to public response" (at 251), and the vulgar Marxist version of it-once again wrongly attributed to cls by Massey (MR at $1270 \mathrm{n} .3$ ) - that asserts that the law is "dominate[d]" by "elite[s]" (at 248). As Kelman notes (id.; see also 251-53), even the most "hard left" of cls scholars

seem to find it far harder [than traditional Marxist historians] to believe that elites dominate each decision that is made, whether because the legal system may be relatively autonomous, because ideological consistency imperatives may overcome result orientation, or simply because less is at stake materially in each intrasystemic dispute than the elite dominance theorists at least sometimes imply.

Indeed, the principal contribution of cls scholarship to the study of the relationship between law and society is precisely the opposite of the "elite state capture" theory suggested by Massey's various characterizations. As Kelman argues at some length, cls scholars have for the most part been more interested in the effects of law on society than they have in the effect of society-elite and otherwise-on law (at 249-57). Drawing (id.) on the work of Mark Tushnet, ${ }^{39}$ Karl Klare, ${ }^{40}$ Jerry Frug, ${ }^{41}$ and especially Robert Gordon, 42 Kelman argues that law "significantly defines the actors who are frequently pictured [by the functionalists] as the social base that influences law" (at 253, emphasis in original), and that the conceptual structure of legal thought and discourse often frames and limits our "understandings of the issues at stake" (at 250). ${ }^{43}$ Critical scholarship is thus notable for its notion of a mutually constitutive and interpenetrating relationship between law and society and hence for its rejection of the simplistic functionalism attributed to it by Massey.

Massey's single attempt to provide concrete evidentiary support for his contrary claim-his assertion that "Kelman thinks the abortion liberal-

39. "Perspectives on the Development of American Law: A Critical Review of Friedman's 'A History of American Law," ' 1977 Wis. L. Rev. 81.

40. "Judicial Deradicalization of the Wagner Act and the Origins of Modern Legal Consciousness, 1937-1941," 62 Minn. L Rev. 265 (1978).

41. "The City as a Legal Concept," 93 Harv. L Rev. 1057 (1980).

42. "Critical Legal Histories," 36 Stan. L. Rev. 57 (1984).

43. Remarkably, Kelman leaves out of this part of his discussion Duncan Kennedy's unpublished magnum opus on legal consciousness-clearly the seminal work of this genrewhich has been circulating in manuscript form since the mid-1970s. A portion of this important piece finally saw the light of day in Duncan Kennedy, "Toward an Historical Understanding of Legal Consciousness: The Case of Classical Legal Thought in America, 1850-1940," 3 Res. L. EF Soc. 3 (1980). 
ization wrought by Roe v. Wade, 410 U.S. 113 (1973), 'may have been responsive primarily to the demands ... of men who wanted to strip women of a major socially functional barrier (fear of pregnancy) to men's demands for sexual access" "(MR at $1270 \mathrm{n} .2$ )--is a complete failure, and an embarrassing one at that. The source of the view expressed in the quoted passage is Andrea Dworkin, and Kelman does indeed offer it as an example of the "elite state capture" theory Massey describes (at $247 \&$ n.27, citing a passage from Dworkin's Right-Wing Women (1983)). But while Kelman concedes that individual cls scholars have occasionally advanced views consistent with such a theory (at $247 \&$ nn.22-23) -and have cited works from outside the movement that adopt it (id. \& nn.24-27)-Kelman makes it perfectly clear that he rejects this view and in point of fact introduces the passage that Massey quotes with the observation that "the trend in CLS is toward skepticism of the sorts of claims I shall now review" (at 247, emphasis added). If there were any remaining doubt on the matter, Kelman moves on two pages later to describe the scholarly work of Tushnet, Klare, Frug, and Gordon-outlined in the previous paragraph-that vigorously rejects such notions of "elite state capture" (at 249-57). In sum, then, not only does Kelman not subscribe to the position Massey attributes to him and to cls; he goes to some length to dispute it. ${ }^{44}$

The difference between the crude functionalism Massey attributes to cls and the far more complex theoretics that cls scholars have actually developed and deployed can perhaps best be understood through a close examination of Massey's related assertions that Kelman "dismisses democratic processes (the electoral system is 'simply . . . a blinding deflection')" and "thinks distinctions between courts and legislatures wholly irrelevant"

44. For examples of similarly sloppy reading by Massey, compare MR at 1273 n.11 (suggesting that Kelman accepts a naive Hohfeldian analysis of "correlativ[e]" rights and duties "between individuals") with Kelman at 279-84 (criticizing that version of Hohfeldian analysis); and compare $M R$ at 1285 (asserting that cls "fails to come to grips with the fact that legal norms often go wholly unobserved") with Kelman at 246 (noting the importance of that very insight to the cls critique of functionalism).

To be fair to Massey, it should be noted that in an earlier review of the Guide Judge Posner misread the abortion passage in exactly the same way. See Posner, Wall St. J., 27 Jan. 1988, at 23 (cited in note 14) (asserting that Kelman "thinks the decision in Roe vs. Wade may have been intended to give men freer access to women by reducing the consequences of an accidental pregnancy"). On the other hand, the content and wording of this and other points in Massey's piece bear such a striking resemblance to the corresponding points in Posner's that it is difficult to ascribe the identical misreadings to coincidence. Compare Posner (asserting that Kelman's book is "marred by stridency and turgidity, as well as by exaggeration and a patronizing tone") with MR at 1270 n.2 (book is "turgid, strident, ... exaggerated, and condescending"); and compare Posner (asserting that Kelman attacks efforts "to depict law as a reasonably objective, reasonably disinterested, reasonably nonpartisan, reasonably civilized method for resolving conflicts and securing . . . widely shared values") with MR at 1270 (Kelman challenges "the notion that law is a reasonably neutral, objective, and civilized method for resolving conflicts and maintaining widely shared societal values"). Massey, however, never mentions Posner's review. 
(MR at 1281). Far from "dismiss[ing] democratic processes," Kelman stresses (at 198) that few if any cls scholars "denigrate the real significance of traditional electoral participation in the Western democracies; I, for one, certainly have no doubt that, because we can vote, we are significantly empowered to control aspects of the direction of community life that would be far harder to control by other means." Kelman's point is yet again precisely the opposite of the one suggested by Massey: Compared with liberal ideals, our institutions are nowhere near democratic enough. Thus, Kelman identifies the distorting effects of class and race on the ability of many citizens to participate in democratic self-governance, though his arguments are structural and systemic in nature and bear scant resemblance to Massey's characterization of them as tantamount to the naive functionalist claim that "the legislature is essentially a collection of racist, elitist, venal stooges of the dominant economic elite" (MR at 1283). Drawing extensively on an article by Richard Parker, ${ }^{45}$ Kelman argues instead that our aspirations to genuinely representative self-governance are undermined by such factors as the alienation of many nonvoters who may be "discouraged, disengaged because of their powerlessness, withdrawn because they are aware that they would be unable to bring their distinct agendas to fruition" (at 196); the relative ineffectiveness of many citizens who do participate because "the capacity to act in the political sphere is not just randomly distributed but class correlated" (at 196-97); the fact that "what counts as a plausible topic for legislative debate may be far more class biased than decisions within the constricted agenda would appear to be" (at 197, emphasis added); the existence "of lobbying, of backroom dealing, of unscrutinized last-minute changes in technically complex legislation about which some constituencies are far better informed than others" (id.); and the likelihood that the voice of "groups that tend to be outsiders in the political process (like prisoners)" will not be heard "when they are represented by people who may have only a general, weak concern for their welfare" (id.).

But even these systemic class-related impediments to genuine self-governance pale in comparison with the phenomenon that, as Kelman correctly notes, cls scholars have always emphasized: the relative absence of democratic control over what our traditions of legal discourse treat as "private" sector institutions, whose decisions vitally affect the lives of citizens every bit as much as do those of the state (at 197-99; see also 102-9). Thus, as Kelman observes, cls has vigorously challenged the exclusive focus on the "public" sphere of social life that characterizes the work of many mainstream scholars "ostensibly concerned with disempowerment" (at 198). ${ }^{46}$ Kelman explains (at 198-99, emphasis in original):

45. "The Past of Constitutional Theory-and Its Future," 42 Ohio St. L.J. 223 (1981).

46. There he goes again, suggesting with yet another condescending adverb that what 
Most of our daily experiences of thorough disempowerment, of subjection to the kinds of power we associate with truly totalitarian imagery, are in relation to people who are in the liberal imagination's private sphere, whether teachers, husbands, or, most significant in the Marxist tradition, bosses. ... [T] he struggle for fuller empowerment in that critical sphere seems so skew to the issue of, say, overreaching courts that one wonders whether ... [cls] and those in the mainstream are observing the same world of powerlessness.

Thus, Kelman's argument is not at all, as Massey would have it, that "the electoral system is 'simply . . . a blinding deflection' " (MR at 1281)-let alone is it that "distinctions between courts and legislatures [are] wholly irrelevant" (id.). Rather, the "blinding deflection" to which Kelman refers is the nearly exclusive focus of traditional liberal scholarship on the "problem" of the supposedly undemocratic nature of adjudication-a focus that blandly assumes that our current legislative structures are by contrast the modern equivalent of the New England Town Meeting and that in any event virtually ignores the existence of a vast terrain of purportedly "private" decision making where democracy dare not tread (at 200). ${ }^{47}$

$* * * * *$

Massey concludes his argument here with the same punchline he delivered with his claims about choice and determinism, asserting that "[p]resumably the dictatorship of an enlightened elite in a utopian postliberal world is the answer served up by CLS" (MR at 1281-82; see also id. at 1290). Now Massey does not contend-nor can he, given the factsthat either Kelman or anyone else associated with cls has ever actually said such a thing or anything like it; rather, he calls his view of the cls position a "hunch" (id. at 1282). How Massey arrives at this "hunch"-how he could conceivably conclude, from a series of cls insights about the way in

is involved is deliberate and self-conscious rather than simply an artifact of the very structures of thought cls has endeavored to identify and critique.

47. Massey altogether misses this facet of Kelman's argument, perhaps in part because its causal valance runs in a direction precisely opposite the simple elite-interests-determinelaw functionalism he seems to see in every nook and cranny of cls thought. This is ironic indeed, given Massey's not-so-subtle Red baiting. See, e.g., MR at 1274 (referring to the "perhaps Marxist perspective of CLS"); id. at 1281-82 ("Ip]resumably the dictatorship of an enlightened elite in a utopian post-liberal world is the answer served up by CLS"); id. at 1289 \& n.50 (noting that Kelman "claims not to know" what a better world would look like, but asserting that "[i]t is hard to take th[is] claim seriously, given the evident fascination of CLS thinkers with Marxist tropes"); id. at 1290 (suggesting that cls supports an "authoritarian radical-left vision of a neo-Marxist community"). As Kelman says of the cls critique of the public/private distinction in liberal legalism, critical scholarship is "perhaps more traditionally Marxist in this regard than in any other I can discern" (at 198); compare the argument in text with, e.g., Georg Lukács, History and Class Consciousness: Studies in Marxist Dialectics 83-222 (R. Livingstone, trans.; Cambridge, Mass.: MIT Press, 1971). Thus, Massey missed his best chance to paint cls with the broad brush of Marxism and make his claims stick. 
which law and society are mutually constitutive and in which legal thought may distort our ability to imagine a more authentically democratic community, that what cls is "really" after is a "dictatorship"-is the subject of the next section..$^{48}$

\section{ASKING THE WRONG QUESTIONS}

\section{A. The "Vision" Thing}

Throughout his review of the Guide, Massey repeatedly refers to the existence of a "utopian CLS vision" (MR at 1275; see also id. at 1274, 1282,1295 \& n.84), and repeatedly chides Kelman and other cls scholars for their "refusal" to "disclose the details" of that "vision" (id. at 1275 (twice); see also id. at 1271, 1289); indeed, Massey repeatedly suggests that cls scholars might not even "kno[w]" the contents of that "vision" themselves (id. at 1275 (twice); see also id. at 1289). It never seems to occur to Massey that he might be the one with the "vision" thing-that it is his agenda at work here, not ours. I refer not to his Red baiting, although that is too obvious to be anything but intentional.49 I refer instead to Massey's not-so-tacit premise that you've just got to have a "vision" if you want your legal scholarship to be taken seriously.

Consider, for example, Massey's abrupt dismissal of Kelman's examination and critique of liberalism's contradictions:

For there to be significance in these criticisms it is essential that Kelman establish both that there is some escape from the incoherence he sees and that there is a moral or practical failure of the liberal world he describes. ... Even if CLS criticisms are meaningful, there is no alternative vision described in anything other than the most general or abstract terms. (Id. at 1271, emphasis added)

Just what is Massey saying? That it doesn't matter whether cls is rightwhether its insights and arguments help us better to understand the recurring conceptual structures of legal thought and argument? That such insights lack "significance" and are just not "meaningful" if we don't propose some means of "escape" from those underlying structures? That even if our criticisms are "meaningful" and "significant," we should keep them to ourselves unless and until we can offer an "alternative vision"? Indeed, the payoff comes when Massey demands not only that cls scholars

48. It is tempting to speculate what the result would be if I were to try to convince a respectable law journal to permit me to publish the suggestion that scholars associated with, say, the Federalist Society want to impose a "dictatorship of an enlightened elite in a utopian post-liberal world" and to offer as authoritative support only my "hunch." But I won't.

49. See discussion at note 47 supra. 
propose a means of "escape"-an "alternative vision"-but also that we "establish" that "there is a moral or practical failure in the liberal world [cls] describes." Now there's a tall order. (Or half-order, anyway; if I were attempting to defend the current "liberal world," I don't think that I would even mention the possibility of "practical failure," given the current crises in our airline, agriculture, automobile, banking, computer hardware, education, health care, insurance, mass transit, and retail merchandising industries; the simultaneous degradation of city, suburban, and rural life; and the catatonic response of our politics and our governing institutions to all of the above.) But in insisting that cls must "establish" that liberal legalism is a "moral failure," Massey has unwittingly stacked the deck: How can cls (or anyone else, for that matter) discharge that burden unless we indulge in the conceit that we have access to some moral yardsticksome "alternative vision"- against which we can make such a judgment? As I said a moment ago, then, this "vision" thing is Massey's; he is the one who insists that cls must point the way to some "utopian post-liberal world" (MR at 1282)..$^{50}$

The apologetic assumptions embedded in this kind of argument-and the dissent-silencing effects that attend their widespread acceptance-may be difficult to see when it is our own professional habits of thinking and structures of discourse that are at issue. But they are embarrassingly obvious when examined in the context of another discipline. Let us pretend, for example, that we are research scientists attempting to find a cure for some deadly infectious disease. Let us further assume that there is a drug already on the market that has thus far proven to be reasonably effective in delaying the onset of the illness among those already infected and in diminishing the symptoms once the disease takes hold. Now imagine that a group of young researchers publishes a series of follow-up studies that strongly suggest that the drug in question causes side effects that are obscured in the early stages by the symptoms of the underlying disease, but that in the long term independently produce horrible consequences. Consider our likely reaction to an evaluation of those follow-up studies that mirrored Massey's critique of cls, particularly if it was published by someone whose own research was called into question by the new studies:

For there to be significance in these studies it is essential that the authors establish that there is some escape from the side effects they see. Even if their criticisms are meaningful, there is no alternative

50. To be completely accurate, Massey does not seem to take personal responsibility for making these demands; rather, he simply invokes the subtle but imposing authority of the Brooding Omnipresence with a passive construction. "II]t is essential," he declares, that our insights and arguments meet his criteria if we want them to be "meaningful" and "significant" (id. at 1271, emphasis added). (As Pierre Schlag would say, "Look, ma, no subject!") 
treatment described in anything other than the most general or abstract terms.

Placed in this less familiar context, the critique can be seen for what it is: a desperate attempt at turf protection that is utterly beside the point on the merits. Indeed, the young researchers might respond, how can a responsible search for the "alternative treatment" that might provide an "escape" from the current predicament even be contemplated without an honest and painstaking examination of the predicament itself ? $^{51}$

$$
* * * * *
$$

I can almost hear my mother's likely reaction to all of this: "Honey, why don't you and your friends just answer their question? Would that really be asking so much? What would you put in its place?" Well, Mom, we can't answer that question, and that's what's so weird about critical legal studies. We can't because the question itself presupposes virtually every assumption about law and legal scholarship that we are attempting to bring to the surface and to call into question. We can't because we just don't think that "the law" works in anything remotely like the way that the question suggests, and we don't entertain the delusions of grandeur evidently harbored by those who think that the question can be addressed in a "significant" and "meaningful" manner.

What would you put in its place? indeed. As the earlier discussion of the cls critique of functionalism illustrates, it is simply not very useful to talk about law in general —or about its liberal legalist variant in particular-as if it had a "place." The point of critical scholarship is that the law is far better understood as a significant aspect of the complex interplay between our culture and our structures of thought than it is as something that has some sort of room of "its" own. We can't step outside of "law" and look at it; we are looking at $u s .{ }^{52}$ And although it is surely the case that some of

51. In fact, it is not at all difficult to imagine a reaction of the medical or scientific establishment to the hypothetical follow-up studies that would look a lot more like Massey's critique of cls than my argument suggests; that, I gather, is a principal lesson of Thomas Kuhn's pathbreaking work, The Structure of Scientific Revolutions (2d ed. Chicago: University of Chicago Press, 1970). But it may sometimes be easier to identify the apologetics of normal science in a field other than one's own, since the constraints of the dominant orienting paradigms and/or of self-interested stakes in the "system" may exert less force on the outsider than on those who work within the discipline in question. To cite an example of this phenomenon that I found particularly striking when it occurred, in 1986 I delivered a paper on the Realist-cls indeterminacy critique to a convention of undergraduate pre-law advisers, most of whom were, as it turned out, political scientists. I had fully expected my arguments to cause great controversy-I had friends elsewhere in legal academia who were, after all, getting fired for articulating such views-but the reaction of most of my audience that day was something like, "You all are just figuring that out?" (The only person publicly to take issue with my views was, naturally, a conference participant who was a retired local judge.)

52. Quite apart from its extraordinary usefulness as a teaching tool, the key insight of Jeremy Paul's "bedtime story"-in which a child attempts to convince her baby-sitter to permit her to stay up past her usual bedtime-is its demonstration of the many ways in 
us speak as if we have found a vantage point from which to examine this interplay "from the outside"-a privileged position of our own, so to speak-I suspect that most critical scholars would readily admit that the opposite is the case, that we experience the same contradictory beliefs and impulses (self vs. other, public vs. private, rules vs. standards, intentionalism vs. determinism, etc.) as everyone else. ${ }^{53}$ The difference lies in our attempts at self-conscious awareness of these antinomies and their animating conceptual structures-and in our sense that this is a legitimate and in fact vital area of scholarly inquiry if we are to avoid mere apologetics-not in our successes thus far in overcoming them. ${ }^{54}$

And if the notion of law's "place" is problematic, what are we to make of the suggestion that the law can be "put" at all? Again, a principal contribution of critical scholarship lies in its rejection of the claim that "the direction of causality [in the development of law] is wholly from private desire to public response" (at 251). Again, the critical view has been that law and society are mutually constituting; there is simply no way for us to "put" law in its "place" because it is always and already $(t)$ here. Moreover, the assumption that it is meaningful to talk on a broad scale about the

which our everyday experience of moral contention matches quite closely with the conflicting rhetorical structures of legal argument. See Jeremy Paul, "A Bedtime Story," $74 \mathrm{Va} . \mathrm{L}$ Rev. 915 (1988). Paul elaborates this point thoughtfully and persuasively in 69 Tex. L Rev. at $1815-20$ (cited in note 4).

53. The use by cls scholars of "liberalism" or "liberal legalism" as a short-hand description of the dominant cultural/professional/ideological assumptions we are attempting to explore and criticize may well account for the not uncommon impression that we think we have somehow transcended these contradictory modes of thinking, rather than (not so) simply attempting to bring them into view. That, I take it, is Mark Hager's point in his excellent review of the Guide: "I cannot see what could be thought specifically liberal about the contradictions identified-rules/standards, value objectivity/subjectivity, free choice/determinism. They can, it seems, more plausibly be viewed as existential or structural than as specifically liberal." Mark Hager, "Against Liberal Ideology: A Guide to Critical Legal Studies, by Mark Kelman," 37 Am. U.L. Rev. 1051, 1057 (1988) (book review) (emphases in original). That the modes of thought at issue are not the exclusive domain of those who might commonly be referred to in legal, academic, or political life as "liberals" is surely right, though that is a much narrower meaning of "liberalism" than most cls scholars have intended since Roberto Unger offered a rather more capacious description of it in Knowledge and Politics at, e.g., 6-7 (cited in note 22). For this reason, I think that Pierre Schlag has made a brilliant, even discourse-shifting move in identifying "normative legal thought" as the target that is also our situation, since that expression avoids some of the "just-who-areyou-including-here" confusion that attends the use of "liberalism." (On the other hand, it may simply generate a larger class of enemies.)

54. As my colleague Steve Winter has argued:

There is no way to get outside of time and existence, no way to escape the field of social interaction that is the self and that the action of the self maintains, no way to transcend-even for a moment-the constitutive action in which the self is already situated and in which the self is always implicated. Sometimes, we can relax the particular scheme by which we separate subject-from-object-from-context long enough to attend to the ways in which it constructs our world. But there is never a moment of privilege because there is never a moment outside a process of construction. What is possibleand all that is possible-are studied acts of situated self-consciousness.

"Without Privilege," 139 U. Pa. L. Rev. 1063, 1068 (1991) (footnotes omitted). 
ways in which we might remake social life solely through a change in legal rules and structures partakes of precisely the kind of crude functionalist fantasy that critical scholars have long sought to debunk. Thus, even if we had a program, we are perhaps more aware than anyone else of the slim possibility that we could "put" it anywhere-let alone that it would have anything like the intended effect once it got there. ${ }^{55}$

Which brings us to the "you." What would you put in its place? is not, after all, addressed to the members of Congress or to the Justices of the U.S. Supreme Court-folks who do indeed expend a great deal of time and effort at projects that perhaps in some vastly oversimplified meaning of the expression could be viewed as "put[ting]" the law in its "place." Presumably, the "you" is instead law professors who, to judge from my own experience anyway, write law review articles that are read mostly by (1) the author's friends and the more industrious scholars who work in the author's field; (2) the author's strongest supporters and/or opponents on the promotion and tenure committee, and/or the outside reviewers each group may hire to assist them with their tasks; (3) law clerks to busy judges, who almost invariably cite the article in question for precisely the opposite point of the one the author was trying to make and not always with a "but see"; (4) two groups of students: (a) a handful of law review editors, most of whom focus on the accuracy of citation in a particular section or passage and never even see the entire piece, and $(b)$ the slightly larger number who take a class in the relevant field from the author and (here's the "slightly" part) do all the assigned reading for the course; and (5) the more courageous and/or foolhardy members of the author's close family. Putting the best face on it, we are talking mostly to each other and our students, an important task indeed. But you would never suspect that this is the audience at stake from reading most legal scholarship, since we almost invariably write as we were playing Merlin to the Supreme Court's Wart and the

55. I am reminded of a faculty seminar $I$ gave at the beginning of my second year at Miami. Although I had practiced labor law for five years before entering academia, I had never noticed until I attempted to teach the subject for the first time that virtually all of the statutory, administrative, and judicial exclusions of working people from the coverage of the National Labor Relations Act-e.g., managerial employees, supervisors, independent contractors, students (like hospital house staff)-seemed to reflect precisely the same set of cultural-legal assumptions about the importance of separating employment from ownership and of distinguishing the conception of work from its mere execution. My senior colleagues listened politely and asked their usual slew of thoughtful and interesting questions, but the session nearly fell apart when I was asked (you guessed it) what I though should be done about all of this. When they were not satisfied with various versions of my initial response- "Isn't it enough that I've seen something no one else has ever noticed?"-I could no longer suppress the bad boy in me and provided the answer that a handful had feared all along: "Transfer the means of production to the working classes." (The response I would give today: "Amend the Labor Act to instruct NLRB members, judges, and labor lawyersnot to mention working people and their employers-to stop thinking this way about work." Whatever else can be said for a decade of experience in legal academia, it has greatly sharpened my sense of irony.) 
Justices were listening attentively, attuned to our every nuance; indeed, we often write as if we were a Justice of the U.S. Supreme Court, or at least a legal academic's idealized version of one. ${ }^{56}$

Viewed this way, the fear that cls seeks a "dictatorship of an enlightened elite" begins to look a lot like a massive neurotic projection: It is the critics of cls who seem to believe they are sitting on the shoulders of judges, offering sound and solemn normative prescriptions for how best to "put" law in its "place"; it is otherwise hard to fathom why they keep asking how we think we might go their imaginary enterprise one better. No wonder, then, that critical scholars who are not even interested in trying to answer that question-who insist instead on taking it apart and showing all of its conclusion-assuming premises-are perceived as so threatening. We are tugging like Toto at the curtains of mainstream legal thought. 57

\section{As Pierre Schlag has astutely observed:}

Not surprisingly, those theories that are the most popular within the legal academy are those that project the most attractive self-image. Consider, as an example, Dworkin's theory of law as integrity and his depiction of the ideal judge as "Hercules." ... Regardless of whether Hercules is an accurate or a desirable model of the appellate judge, he certainly resonates profoundly in the self-image of the contemporary legal academic. Indeed, it is easy to understand Hercules as the projection of the legal academic's idealized self-image onto the character of the appellate judge. Similarly, Dworkin's theory of law as integrity can easily be understood as a projection of the kind of elegant theoryconstruction that characterizes the most esteemed legal scholarship onto the appellate judicial opinion writing process.

139 U. Pa. L. Rev. at 844-45 (citation omitted) (cited in note 17).

57. There is a considerable body of cls-associated work that does offer what look for all the world like "constructive" proposals, many of them quite concrete and within the realm of the politically plausible. See, e.g., Karl Klare, "Workplace Democracy \& Market Reconstruction: An Agenda for Legal Reform," 38 Cath. U.L Rev. 1 (1988). Those who insist that cls has never engaged The Question either ignore this work, dismiss it as unresponsive to the broader normative enterprise, or strike the pose of what Jerry Frug has called the "modest realist":

[M]odest realists tend to respond to their critics' concrete suggestions for change in the manner of a sober grown-up addressing a naive child. If the suggestion is "in the ballpark," they treat it as one more factor that needs to be "weighed" against a host of other competing factors, and the likelihood that they will accept the suggestion is low. Chances are that it has already been weighed and found overridden by other factors, or has already been taken into account to the extent that it has merit, or has yet to develop a sufficient track record to be seriously considered, or is simply too trivial a revision of the status quo to be worth pursuing. If, on the other hand, the suggestion proposes some radical change, the modest realist dismisses it out of hand as utopian. "Things are complicated and difficult," one almost hears the modest realist saying, "Of course we have a long way to go. But everything is a tough policy choice, and every decision we make will have its faults. All we can do is the best we can."

Gerald E. Frug, "The Ideology of Bureaucracy in American Law," 97 Harv. L. Rev. 1276, 1383 (1984) (footnotes omitted).

The upshor is a double-bind for those doing critical scholarship: Refuse to engage The Question, and your arguments are either dismissed as insignificant or mischaracterized as dangerous. Engage The Question, and your proposals are ignored, conventionalized, or dismissed as utopian. All this reveals a great deal more about the rhetorical structures that fortify mainstream legal thought against critique than about the supposed failure of the critics to come up with "constructive" proposals of their own. 


\section{B. Normativity Redux}

The mainstream assumption that legal scholarship must above all other things be prescriptive-normativity $u$ ber alles, as Massey might put it were he in our position-has a multitude of distorting effects that Pierre Schlag and his critique-of-normativity confreres have begun to unearth and criticize. My principal point here is that the relentless What would you put in its place? thinking of mainstream scholars has been the principal source of their systematic misreading and misunderstanding of cls work: Armed with only a hammer, everything around them begins to look a lot like a nail. It is accordingly a short leap from the mainstream premise that cls should be normative to the assumption that it is so-that it does have a "vision" or a program, and that the refusal of its adherents to disclose it strongly suggests that they have something truly awful to hide. They must be Stalinists.

Listen one last time to Massey ( $M R$ at 1275 , emphasis in original):

Kelman's refusal, or inability, to disclose the details of the utopian CLS vision saps much of the force from his contention that rules and standards are hopelessly in conflict and operate to prop up the ancien regime. My suspicion is that Kelman would simply prefer a capture of the legal system from within, by substituting his privileged constructs for those he sees currently in place, without revealing, or even knowing, the nature of the substantive change thereby wrought.

We can now begin to understand how the "vision" thing-operating against the backdrop of the patterned contradictions of liberal legal thought-might lead mainstream readers to think they see a hidden agenda of a particular kind in the cls critique of the privileged positions. If your working assumption is that legal scholarship must be programmaticmust provide an "alternative vision" and describe a means of "escape" from our current practices-then Kelman's critique of the privileging of (for example) intentionalism must be deployed in the service of some alternative, of "substituting his privileged constructs for those he sees currently in place" (id., emphasis in original). And if you work within an epistemic framework in which everything is (to continue the same example) either intended or determined, then the preferred alternative must be the mirror image of the intentionalism Kelman so astutely deconstructs-to wit, determinism. Bingo: Critical legal studies is B. F. Skinner and beyond either freedom or dignity.

This, then, may well be how scholars like Massey can come to wild conclusions like "[t]he CLS vision is of a world where choice is illusory, where we are all determined by extrinsic factors" (id. at 1294). But not only is this claim just plain wrong on the facts-as I have argued at some 
length, nothing in the cls critique of intentionalism even remotely supports such a characterization-it is also a product of the very intellectual structure we are trying to explore and to challenge. For it is liberal legalism that first insists on a "vision" and then presents the debate about its content in either/or intentionalism-versus-determinism terms, thus fashioning a context in which legal scholarship becomes a sort of referendum through which individual academics cast their votes for one or the other depending on the doctrinal context. By contrast, critical scholars are far more interested in the underlying phenomenon itself: Why do we-conservatives, liberals, and left-progressives alike-seem to divide up our experience of the world in this way? And what are the implications of our doing so for legal thought and practice? ${ }^{58}$

\section{WHO ARE THE BRAIN POLICE?}

We can now begin to account for the striking regularity with which mainstream legal scholars get their facts wrong when they discuss and analyze critical scholarship. Whether it's Dean Paul Carrington calling Roberto Unger-Roberto Unger! - a "nihilist" 59 or Ronald Dworkin making the ridiculous and utterly undocumented claim that some within cls deploy their arguments in the "service of undisclosed political goals," 60 normative legal thought cannot be very far behind. To further explore the analytical structures that have helped to produce this state of affairs, let us turn to several other reviews of Kelman's Guide and watch as scholars as diverse as

58. The greatest difficulty that cls may face here is to avoid an essentialist leap that would elevate this experience of contradiction to ontological status, concealing the prospect that it is a particular and situated epistemological moment (albeit a really long one) in the construction of which we are ourselves deeply implicated. See, e.g., David Gray Carlson, "Contradiction and Critical Legal Studies," 10 Cardozo L Rev. 1833, 1854 (1989) (book review) ("For Hegel, contradiction has meaning, and more! Contradiction, for Hegel, is the very substance of our lives. It is not to be regretted or denied but embraced as both the fact of our finitude and our salvation from it") (emphasis in original). In this connection, my colleague Steve Winter is surely right when he argues that critical scholars and mainstream legal thinkers alike seem to "participate in exactly the same understanding of objectivity and subjectivity as mutually entailed, dichotomous choices." Steven L. Winter, Foreword: "On Building Houses," 69 Tex. L. Rev. 1595, 1597 (1991).

59. See Paul D. Carrington, "Of Law and the River," 34 J. Legal Educ. 222, 227 \& n.21 (1984). As Robert Gordon observed in his thoughtful response to Dean Carrington's claim:

[W] hom is it realistic to call a nihilist? Surely not a romantic Christian Hegelian like

Roberto Unger, who has just set off to spend several years of his life doing grass-roots political organizing in Brazil; there are few people anywhere in the world who have given more effort to constructing a theory of social transformation and shown more courage in trying to carry it out in practice: in his case at least, the proper analogy is not the one you suggest to an atheist in a divinity school, but rather to a liberation theologian.

Letter from Robert W. Gordon to Paul D. Carrington, in " 'Of Law and the River,' and of Nihilism and Academic Freedom," 35 J. Legal Educ. 1, 13, 14-15 (1985).

60. Dworkin, Law's Empire 275 (cited in note 30). Presumably, he has a list of names. 
Richard Barnes, Daniel Farber, and Eugene Genovese drink from precisely the same waters as Massey. Although these individuals do not undertake anything like the detailed critique of the Guide offered by Massey, we will see that the pertinent portions of their reviews nevertheless replicate the basic structure of his analysis: (1) ask the What would you put in its place? question and insist that an adequate response must provide an "alternative vision"; (2) infer from the absence of an articulated vision that there may well be a program (invariably some form of a "dictatorship of an enlightened elite in a utopian post-liberal world") hidden between the lines of cls work-a program so well hidden, in fact, that it turns out on close examination not to be there at all. For easy reference, we'll refer to the two moves thus: Ask the question/demand an alternative vision; Posit a hidden program/get the facts urong. ${ }^{61}$

61. It should perhaps be noted that the penchant for asking the What would you put in its place? question is sometimes observable among cls insiders as well. Consider, for example, the review of the Guide written by John Stick, who has closely identified himself with what he calls a "countertradition" within cls-a tradition that he defines in terms of its rejection of the "mainstream" cls view on indeterminacy and legitimation. 88 Colum. L. Rev. at 408 (cited in note 13). Drawing on an earlier piece, Stick argues that Kelman and other critical scholars find a "failure of moral and political justification" in the materials of legal decision making because they are testing those materials against a model of rationality that is very different from-and much more restrictive than-the one that common law lawyers and judges actually deploy. Id. at 413 \& n.18, citing John Stick, "Can Nihilism Be Pragmatic?" 100 Harv. L. Rev. 332, 345-69 (1986). Legal reasoning, the argument goes, is not confined to logical deduction or something akin to "mathematical calculation"--as the crits assertedly assume-but rather includes the active use of "legal culture, conventions, common sense, and politics." 100 Harv. L. Rev. at 356; see also 88 Colum. L. Rev. at 413.

Stick gives a fair sketch of the experience of legal reasoning, but what his account misses is what Steve Winter has identified as the discontinuity between that experience and the practice of legal argument and justification. See $137 \mathrm{U}$. Pa. L. Rev. at 1180-98 (cired in note 27). Thus, with rare exception, the rhetoric of legal argument-whether used by a lawyer to attempt to persuade a court or by a judge to attempt to justify a result-is a thetoric of constraint, entailment, and necessity. To be sure, we expect the "legal culture, conventions, common sense, and politics" that Stick describes to have a profound impact on the ways a lawyer or judge will actually think about a case; that is one of the most interesting points of Duncan Kennedy's insightful piece on the phenomenology of judging. See "Freedom and Constraint in Adjudication: A Critical Phenomenology," $36 \mathrm{~J}$. Legal Educ. 518 (1986). But we would think it highly unusual if the lawyer in her brief - or the judge in her decision-relied on any of those factors as a reason for reaching a particular result in a particular case.

The point, then, is that critical scholars are measuring the practice of legal argument against liberal legalism's own professions of constraint and entailment, not against some external standard of "moral and political justification" that cls has independently embraced. Thus, Stick is making the same mistake that Massey made, confusing critical analysis with a form of normative argument that may reveal more about his own rationalist commirmentshowever much they differ from Massey's-than about the views held by other critical scholars. 


\section{A. Richard Barnes}

Ask the question/demand an alternative vision. In his review of the Guide (cited as BR),62 Professor Barnes argues that the book is a "failure" because of Kelman's "inability to make a positive case for CLS by showing that CLS itself posits something other than destruction of the current legal order" (BR at 221). ${ }^{63}$ The required "something," Barnes insists, must consist of the elaboration of "an alternative" to liberalism and "some articulation of the underlying normative propositions"; cls must offer "a "coherent' legal model of its own" (id. at 222). The contributions of critical scholarship in identifying and exploring the patterned contradictions of liberalism are not enough, according to Barnes, for "criticism of the current legal system as being incoherent without a model of how it could be coherent is not likely to engage or entertain those of us who participate in it" (id.). In the absence of "some positive model, some alternative," cls criticisms just aren't "relevan[t]" (id. at 221-22) to mainstream readers and can "d[o] no one any lasting good" (id. at 222).

Posit a hidden alternative/get the facts wrong. Yet cls might have an "alternative program" up its sleeve after all, for according to Barnes (id. at 220, emphasis added and footnote omitted):

While there are hints of the Marxist bent of many CLS adherents, for the most part, [Kelman] leaves the reader to speculate on what CLS is. There is little to suggest what the legal system would be like if reshaped along CLS lines. The picture of the CLS program that coalesces is of some metaphysical anti-matter opposed to the mainstream matter of "liberalism" in the law.

62. 34 S.D.L. Rev. 220 (cited in note 12).

63. According to Barnes, the book is also a "failure" because it is often such a difficult read (id. at 223-25). He has a point: Kelman tends to pack phrases and sentences to the bursting point and to pitch his arguments at an exceedingly abstract level. See, e.g., Guide at 13 ("the legal system is invariably simultaneously philosophically committed to mirrorimage contradictory norms") (emphasis removed). Barnes is surely right that those characteristics make the Guide just about the last thing you would want to give to a lawyer-let alone a lay person-looking for an introduction to cls (BR at 223).

Yet despite the title, it was surely Kelman's prerogative to address an audience of sophisticared legal academics familiar with the jurisprudential debates in which cls plays a significant role and to attempt to enrich and refine those debates, rather than to reduce them to some sort of primer. Indeed, sketching an account of those debates that is accessible but not simplistic is no easy task. The most successful efforts thus far can surely be found in Robert Gordon's work, especially "New Developments in Legal Theory," in Politics of Law 413 (cited in note 6), and "Unfreezing Legal Reality: Critical Approaches to Law," 15 Fla. St. U.L. Rev. 195 (1987). I tried my hand at it once, and the principal reaction of my senior cls-identified colleagues was to advise me to hide the draft in some dark hole, at least until I received tenure. At the same time, the responses of my more mainstream colleagues, of our students and alumni, and of faculty at other schools looking for ways to introduce their own students to cls was for the most part quite encouraging, suggesting that attempts at translation and outreach are well worth their considerable effort. See Richard Michael Fischl, Essay: "Some Realism about Critical Legal Studies," 41 U. Miami L. Rev. 505 (1987). 
The latter point - the suggestion that cls plays "anti-matter" to liberalism's "matter"-is reminiscent of Massey's similar conclusion that Kelman simply wants to "substitut[e] his privileged constructs for those he sees currently in place" (MR at 1275, emphasis in original). But as I argued in the previous section, it is What would you put in its place? thinking that is doing all the work here, not Kelman or cls: It is Barnes who presupposes the need for and hence existence of a "CLS program"; and, finding none, he simply assumes that its commitments would merely turn mainstream liberalism on its head.

And what, pray tell, is the "anti-matter" of liberalism? Barnes's other point-his reference to "hints of the Marxist bent of many CLS adherents" (BR at 220)_suggests an answer. For why the word "hints"? In point of fact, Kelman is quite clear about the intellectual debt that cls owes Marxist theory; indeed, three of the four citations that Barnes offers in support of his "hints" claim refer to a forthright and extended discussion of the matter that appears in the introduction to the book and its accompanying footnotes (id. at 220 n.2, citing the Guide at 9, 10, and 300-301 n.17). ${ }^{64}$ But Kelman's discussion focuses almost entirely on the rejection of traditional Marxist tenets by cls scholars, whose primary focus has been on the role of ideology-rather than material interest and class conflict-in social life and relations. Indeed, Kelman goes on at some length (at 300-301 n.17) in the passage in question to describe critical scholars'

loss of intellectual faith in Marx's teleological determinism, his sense that there were objective laws of historical motion that would result in a particular transformation of social roles, even in the absence of selfconscious political action. Just as traditional liberal theory was fundamentally one-sided in its account of human experience, emphasizing an untrammeled phenomenological perspective, dwelling on subjectivity and intentionality to the exclusion of determinist accounts that repress the subject, so traditional Marxism lacks a cogent theory of politics, of intentionality, of will, emphasizing only the ways in which classes play predetermined objective roles.

64. Barnes's fourth citation-Guide at 298 n.12-refers to a lengthy note in which Kelman astutely describes cls from the vantage point of some of its more hostile mainstream detractors. Here is a representative passage from the argument in question:

At best [cls] may be viewed as a dissident voting bloc at faculty meetings that attempts to prey on insecure and guilty liberal colleagues to build coalitions that will hire only unqualified "politically correct" hacks; undo "meritocratic" (test-based) admissions programs; force students into serving the poor at storefront clinics without any respect for those who believe that they better serve the poor by greasing the wheels of commerce or simply feel that serving the poor is just not what they had in mind.

To the same effect, see Kelman's sarcastic reference (at $299 \mathrm{n.12}$ ) to mainstream academics who fear the adoption of what they see as "the 'party platform' of the CLS wing (or is it cell?)" at their home institutions. Barnes evidently mistook these obvious attempts at parody for "hints of the Marxist bent" among cls scholars. 
Surley this was not the "hints of the Marxist bent of many CLS adherents" that Barnes had in mind. Indeed, the quoted passage quite explicitly rejects Barnes's tacit, and prototypically liberal, premise that we can map the realm of the possible by embracing either untrammeled subjectivity or relentless determinism - that we must privilege either the "matter" of liberalism or the "anti-matter" of vulgar Marxism. But if you start from that liberal premise, then the cls rejection of liberalism can mean only one thing, no matter what scholars associated with the movement actually say.

This would account for Barnes's otherwise enigmatic use of the word "hints": It is not Kelman's discussion of the theoretical differences between cls and traditional Marxism that reveals the former's "Marxist bent"; it is rather the relentless critique of liberalism. And it would also go a long way toward explaining where Barnes might have come up with the idea-suggested without citation six times in the two pages that follow the "Marxist bent" remark-that the aim of cls is nothing "other than destruction of the current legal order" (BR at 221, emphasis added; see also id. at 221-22). He certainly could not have derived that notion from a book that goes to such great lengths to reject the functionalist fantasy that we can remake social life simply by changing legal structures (at 242-68)nor from a movement whose principal point has been that it is ideas that matter, and whose participants more traditional leftists routinely deride "as hopeless idealists, preoccupied with the empty words and sham ideas that those exercising authority use to explain their conduct" (at 10, footnote omitted). No, the notion that critical scholars are really out to "destr[oy] the current legal order" and to offer some form of vulgar Marxism as the "anti-matter" replacement for liberalism seems to have sprung fully formed from the head of Barnes. Or, to be more precise, from the What would you put in its place? thinking of Barnes and others like him.

\section{B. Daniel Farber}

It should perhaps be noted at the outset that Professor Farber's review of the Guide (cited as FR) appeared not in a law journal but in the New Republic. ${ }^{65}$ Accordingly, one might be tempted to dismiss the opening lines of the piece as mere hyperbole designed to grab the attention of the magazine's neoliberal (or is it neoconservative?) lay readership (FR at 36): "One of the few remaining strongholds of the New Left has turned out, surprisingly enough, to be legal academia. Talk of social revolution thunders out of Harvard Law School, and radicals stalk the halls of Stanford and the University of Wisconsin." But when as sober and thoughtful a legal theorist as Farber makes three highly dubious claims in the space of 


\section{LAW AND SOCLAL INQUIRY}

his first two sentences, you have to worry a little about what is to follow. After all, legal academia is a "stronghold" of the New Left in about the same sense that it is a "stronghold" of, say, African-American women and out gay men. Moreover, the only thing "thunder[ing]" out of Harvard Law School is the herd of well-dressed graduates headed for jobs with large corporate law firms. And whatever the case may be at Wisconsin, the "radicals" at Stanford include the law school's dean, so I doubt very much that they are relegated to "stalk[ing] the halls" of that august institution. ${ }^{66}$ But after this brief flirtation with gonzo journalism, Farber's review soon gets down to the now familiar task of misreading Kelman in the now familiar way.

Ask the question/demand an alternative vision. "The crits," Farber explains (FR at 39), "have seemed unwilling to explain what kind of society they want, or what kind of social change they would like to see. ... The[y] have never tried seriously to propose concrete social changes; indeed, it is hard to imagine what they could propose that would not be essentially reformist." Echoing Massey's claim that Kelman's criticisms of liberalism's contradictions are neither "meaningful" nor "significant," Farber declares that " $[t]$ he first time you see a crit show that a liberal position is contradictory, incoherent, and fundamentally arbitrary, you are impressed; after you see the trick done often enough, it loses its punch" (id.). Now that's an interesting reaction: Critical scholars demonstrate that, position after position, liberalism is "contradictory, incoherent, and fundamentally arbitrary," and Farber's reaction is that it is cls-rather than liberalism-that has "los[t] its punch."

Posit a hidden program/get the facts wrong. Like Massey and Barnes, Farber gets into trouble when he begins to assume that cls does, in fact, have a program-one that is hidden between the lines of its critique. Disputing Kelman's analysis of liberalism's privileged positions, Farber argues (id. at 39, emphases added): "One of these [privileged] norms is individual autonomy; we require some justification for restrictions on individuals' choices about their own lives. We think the government should have some reason before it interferes with people's choices. This slight presumption in favor of liberty does not strike me as unreasonable." Though we are spared the lecture about "choices mandated for Montana cowboys by a mandarin class of elite academic radicals," Farber makes the same intellectual error here as did Massey. In fact, the argument to which Farber is responding is an internal critique of liberal legalism-an attempt to challenge the privileged rhetorical positions of autonomy and choice by show-

66. Of course, the fact that a crit is now at the helm of a leading law school might be read to support Farber's legal-academia-is-a-stronghold-of-the-New-Left claim. On the other hand, it might be read to undermine the popular image of crits as folks who "stalk the halls," "thunder" about, and hang out in "strongholds." 
ing the many ways in which they misdescribe a legal and social life that is already rife with paternalist interventions. Where, then, does Farber come up with his baseless inference that cls favors "restrictions on" and "interfere[nce] with" private choice even in the absence of any "justification" or "reason" for state intervention? To paraphrase Edgar Allen Poe, Farber is listening to the sound of his own heart beating: It is his What would you put in its place? thinking that leads him to assume that Kelman's analysis is implicitly programmatic, and it is his either/or assumption that autonomy and paternalism exhaust the realm of the possible that leads him to assume that a critique of the former is the same as an embrace of the latter. The ironic result, then, is that Farber projects onto cls the very analytical structures that Kelman and other critical scholars are attempting to question and rethink.

Farber makes the same mistake when he discusses (id. at 38, emphasis added) Kelman's purported atternpt

to rebut the liberal belief that government should not impose a single set of "objectively correct" values on society. One of the fundamental tenets of liberalism is tolerance toward minority religions and ways of life. . . . In post-Reformation society, a wide divergence of fundamental philosophies is likely to exist unless it is forcibly suppressed. The liberal considers tolerance better than repression. And to rebut this view, ... the crits will have to demonstrate that suppressing "undesirable" groups would be a good government policy.

Farber puts the word "undesirable" in quotes, but his review provides no source citations and so it is impossible to tell where he came up with the preposterous suggestion-the slightest support for which can in fact be found in neither the Guide nor in any other cls work I have ever seenthat critical scholars think that "suppressing 'undesirable' groups would be a good government policy." Once again, it is Farber's assumptions that are doing all the work here: A critique of the subjectivity of value must be an argument in favor of something, and that something must be a relentless and authoritarian objectivism, for what else is there?

\section{Eugene Genovese}

Professor Genovese presents a far more sophisticated analysis and critique of the Guide (cited as GR )67 than those offered by Massey, Barnes, and Farber. Among other things, Genovese identifies a common thread in cls scholarship that few of its other critics have noticed: its frequent em-

67. 3 Yale J.L. \& Hum. 131 (cited in note 7). 
brace of a surprisingly liberal view of the primacy of the individual subject. As he says (GR at 149):

From start to finish, in Kelman's Guide and without, [cls scholars] proclaim their war against individualism, and from start to finish they wallow in the individualism they purportedly war against. Kelman, like Unger, Kennedy, and others, begins with the conflicted concerns of the individual and ends with his liberation. ... They extol the community (society, group) and insist that the individual expand his personality with due respect for the personalities of others, but they reject, virtually out of hand, the alternate concept of the prior rights and imperatives of the community. In this respect they follow proudly in the tradition of the great bourgeois theorists from Hobbes to Locke and Blackstone and Burke, and beyond. ${ }^{68}$

Given this important insight about the unreconstructed liberalism of cls, Genovese's readers might well expect a refreshing change from charges of covert Stalinism and the like. But they will be disappointed, for Genovese too finds a hidden Stalinist agenda-albeit one that is, in Genovese's somewhat more generous view, almost surely unintended by those in the movement (GR at 144-45). Indeed, apart from this suggestion that critical scholars are dupes rather than fellow travelers, Genovese's critique of both the Guide and cls more generally replicates the structure of analysis that we have examined thus far in every significant respect.

Ask the question/demand an altemative vision. Genovese's review astutely if somewhat hyperbolically describes the Guide's "synthesis of CLS's familiar, controversial, slashing attacks" (id. at 132) on "the liberal legal system and its dichotomies of rules and standards, the objectivity and subjectivity of values, and the recourse to assumptions of intentionality and determinism" (id. at 133). But Genovese quickly becomes impatient with the seemingly endless stream of criticism and can contain The Question no longer (id.): "There is a limit beyond which any viewpoint becomes dull when it remains on the attack, content to assail other intellectual positions. ... Time after time, a reader wants to cry out: 'Doubtless, it is all a mess. But what, exactly, do you propose to put in place of the legal system you are attacking?" "Genovese complains that the Guide-and cls work generally- "demonstrate" the "contradictions, weaknesses, and failures" of liberal legalism "in a way that merely assumes the existence of a constructive alternative" (id. at 141). But the burden on those who would make such charges, Genovese explains, is to "elaborat[e] and defen[d]" a

68. This tendency is difficult to miss in some of Roberto Unger's work-a point developed at note 69 infra and accompanying text. But an appropriately modern-not to say postmodern-version of it lurks awfully close to the surface in the work of many of the more "mainstream" cls scholars as well. See Schlag, 69 Tex. L. Rev. at 1679-1705 (cited in note 17) ("Critical Legal Sartre"). 
"practical alternative" to "[t]he present social order and legal system" (id. at 134).

Like Massey before him, Genovese is a man in search of a vision. Critical scholars, he asserts, can "justify their negativity only by laying out a minimal social vision that gives people a sense of where they are being led" (id. at 155). Indeed, this explicit assumption that the critical enterprise is "justif[ied]" only if it is accompanied by a constructive "social vision" may well explain why a piece that starts out as a review of the Guide soon mutates into an extended analysis of the collected works of Roberto Unger (id. at 138-43, 146-55), a cls scholar who-as Genovese observes-“does have a positive vision, does struggle to transform negative criticism into constructive theory, does advance the outlines of a political program" (id. at 138). But crits can't even criticize the admittedly brilliant and provocative work of one of their own without confronting Genovese's demand for a program to put in its place: "Unger has a vision," he observes. "The Critics may wish to dissociate themselves from it, but then they have a responsibility to present an alternative that could represent them as a movement" (id. at 155). ${ }^{69}$

Posit a hidden program/get the facts wrong. At times it seems as if Genovese is merely making the same argument as Massey and Barnes: When all is said and done, cls simply must have a program, and its adherents are just refusing to disclose it. Thus, Genovese repeatedly refers to the "political program" of cls (id. at 132 (twice), 135, 145) and even suggests at one point that critical scholars" "intentions and ideological stance come shining through" despite their best efforts to conceal them (id. at 139). But for the most part, Genovese seems to be making a somewhat different point. Critical scholars, he contends, are telling the truth when they claim that they have no particular program-let alone a Stalinist one-in mind. Nevertheless, Genovese warns, their implicit "program contains totalitarian dangers," and those who "have accused the Critics of totalitarianism" are thereby "conflat[ing] the sin with the sinner and the possible outcome

69. Ironically, the most common critique of Unger by other critical scholars is similar to the cls-wallows-in-individualism point made by Genovese and quoted earlier. See, e.g., Drucilla Cornell, "Beyond Tragedy and Complacency," 81 Nw. U.L. Rev. 693, 700 (1987) (citation omitted):

[F]or Unger, attachment is always valued from the vantage point of the self, which somehow or other is present to itself before attachment. The other is for-the-self. [But] the self-present-to-itself in time and space is not only a myth, but a myth based on erasure of the mother. . . . For we come into this world only because we have been attached to one who is already there when we make our entry. The mother symbolizes our inevitable dependence on others and our tie to a world that was already there before us; the "it was" of the past denies to the infinite, willing self the illusion of selfcreation. We do not give birth to ourselves in the continual process of self-transcendence. Instead, we endure birth as we are thrown into a pre-given environment.

Cass Sunstein is evidently the originator of the elegant if horrifying phrase, "erasure of the mother"; he makes a point similar to Cornell's in "Routine and Revolution," $81 \mathrm{Nw}$. U.L. Rev. 869,885 \& n.63 (1987). 
with the intent" (id. at 144-45). And why does Genovese fear that the "possible, indeed probable outcome" (id. at 145) of the supposed cls program is totalitarianism? He defends this claim thus (id., emphasis added and footnote omitted):

Kelman and the Critics cannot easily turn aside the charge that they seek to impose upon others their own notion of what everyone else's inner will needs in order to achieve fulfillment. Their open acceptance of the need for what they call "paternalism" in human affairs does not in itself make the case against them, but the specific kind of argument they are compelled to make does.

Genovese does not describe or discuss the "specific kind of argument" to which he is referring, but rather merely drops a footnote that gives the page references to Kelman's discussion of paternalism-together with a gratuitous "and passim"- and adds: "Kelman shows the CLS to be uneasy about paternalism, and he makes some useful distinctions. But he also shows that, by any other name, a strong dose of paternalism lies implicit in CLS thought" (id. at 145 n.22). At a later point, Genovese seemingly recognizes the tension between the "open acceptance" of paternalism that he attributes to cls in his text and the "uneas[iness]" about it that he describes in the accompanying footnote, but he attributes this conflict to cls and the Guide rather than to his own assumptions (id. at 146):

Kelman and the Critics abhor dependency relations and people who give orders. Their defense of "paternalism" would seem to imply the one and countenance the other, but they make no effort to square the circle. Their argument, as Kelman presents it, comes close to an assertion that dependency is not really dependency when it realizes the dependent's inner will.

Indeed, Genovese anticipates Kelman's likely response to these claims, but-once again directing the reader to the Guide's discussion of paternalism-he abruptly dismisses them: "Kelman might well deny that CLS invokes the doctrine of inner will ... but I see no other way to read him and the Critics generally" (id. at 145 n.21).

Of course, there is another way to read the Guide, but Genovese missed it in much the same manner and for much the same reason that Massey did. Thus, the "specific kind of argument" that Kelman presents in the passage Genovese cites (at 137-41) was an effort to demonstrate that "a strong dose of paternalism lies implicit"-not, as Genovese would have it, "in CLS thought" (GR at 145 n.22)-but within liberal legalism itself. And far from suggesting the "open acceptance" of such arguments by critical scholars that Genovese claims, the passage in question made 
clear that most critical scholars find arguments of this sort deeply problematic and troubling (at 138). How did Genovese arrive at such a misconstruction? In a sense, he was already there. Throughout his review, he makes the same assumptions Massey, Barnes, and Farber did: that what is at stake is, in Genovese's words, "the principle to be privileged" (GR at 137) and that critical scholars, again in his words, "would like to reverse matters and privilege [liberalism's] counter-principle[s]" (id.). Thus, if Kelman presents a sustained and trenchant critique of intentionalism, then, reasons Genovese, he must be in favor of "revers[ing] matters" and privileging paternalism (id. at $145 \&$ n.22). Similarly, if Kelman presents an "often cogent critique of the privileging of rules over standards" (id. at 134), then, reasons Genovese, he must be in favor of "revers[ing] matters" and privileging standards (id. at 134-35). ${ }^{70}$ And if Kelman criticizes the traditional focus of liberal scholars on the democratization of the so-called public realms of social life-and their corresponding tendency to ignore the "daily experiences of thorough disempowerment" at the hands of, say, husbands, "who are in the liberal imagination's private sphere" (at 198-99, emphasis in original)-then, reasons Genovese, he must once again be in favor of "revers[ing] matters" and favor "the privileging of the claims of the state" over those of "the privacy of the family" (GR at 147).

The last of Genovese's points suggests just how profoundly Genovese and others like him have misunderstood Kelman's critique of privileging. Consider Genovese's argument in full context (id., emphasis added):

Much of family life may be put beyond the purview of the state without giving a blank check to wife-beaters and child abusers. The privacy of the family has long been respected while limited. But that arrangement requires the recognition of a legitimate authority in both state and family and an acceptance of such dreaded hierarchy as that of parents over children. ...

The problem concerns the bias brought to bear on the large and unavoidably gray area between the claims of privacy and the necessity for intervention to curb atrocities. On that question, the burden of the Critics'

70. There is in fact some ambiguity concerning Genovese's view of Kelman's position-and the position of cls generally-on the issue of rules and standards. Thus, at one point, Genovese states that "[i]t is not clear to me that Kelman in fact does think [rules] should be dispensed with" (id. at 134). But a few paragraphs later, Genovese approvingly quotes Harold Berman's measured response to the cls criticisms of rules (id. at 134-35): "Berman properly scoffs at the notion that the replacement of the emphasis on rules by one on substance would end well, especially if carried as far as many of the Critics seem willing to go. 'What is to prevent discretionary justice,' he asks, 'from being an instrument of repression and even a pretext for barbarism and brutality, as it became in Nazi Germany?" "One is tempted to answer Professor Berman's question thus: The same thing that will prevent the current Supreme Court's rule-obsessed jurisprudence from serving as "an instrument of repression and even a pretext for barbarism and brutality"- a differently constituted Supreme Court and a different social/legal/cultural context. See Steven L. Winter, "Indeterminacy and Incommensurability in Constitutional Law," 78 Cal. L. Rev. 1441 (1990). 
argument points toward the privileging of the claims of the state. I should suggest that even those of us who place community cohesion above individual right would do well to resist that siren call, lest we undermine the measure of individual freedom that ought to be compatible with social safety.

There is something important missing in Genovese's formulation of the "problem" at issue as a straightforward conflict between "the claims of privacy" and "the claims of the state": the claims of women who experience-within and without the family-a "dreaded hierachy" that Genovese doesn't seem to notice. As Catharine MacKinnon has argued: "The law of privacy treats the private sphere as a sphere of personal freedom. For men, it is. For women, the private is the distinctive sphere of intimate violation and abuse, neither free nor particularly personal. Men's realm of private freedom is women's realm of collective subordination."71 Thus, the argument is not-as Genovese would have it-that liberalism errs by privileging " $t \mathrm{t}] \mathrm{he}$ privacy of the family" and that the error can be cured by simply "privileging ... the claims of the state" (GR at 147). Indeed, in the very passage to which Genovese evidently refers, Kelman goes out of his way to warn that "there are real limitations to focusing political energy on the state" in attempting to deal with the pervasive problem of sexual violence (at $199 \&$ n.35). ${ }^{72}$ The argument is rather that viewing the matter through the traditional liberal lens of privileged private realms versus massive state incursions-Bambi meets Godzilla, over and over and over again-obscures a vital point about the experience of some rather dreadful features of our social life. ${ }^{73}$

71. Toward a Feminist Theory of the State 168 (cited in note 23).

72. The "state" is not, after all, some gender-neutral abstraction. As Mason Williams put it in the somewhat different context of the riots that accompanied the 1968 Chicago Democratic convention, "I'd call the police, but they're already here." See generally MacKinnon, Toward a Feminist Theory of the State 157-70.

73. Genovese's nigh complete erasure of the victim here is of a piece with his snide remarks concerning Kelman's frequent use of the female personal pronoun when the antecedent is not gender-specific (GR at 136-37):

I make no apology to the ladies for usually writing "men" instead of "persons" and always writing "his" instead of "his/her" or God knows what, for I cannot fathom how a commitment to justice and equity for women requires a trashing of the great English language.... What have we come to when men who aspire to speak seriously of serious things degrade themselves by cowering before threatened accusations of sexism?

From which I suppose we are to gather (1) that persons other than "ladies" (gentlemen?) shouldn't be offended by sexist language; (2) that "men" (but not women?) who endeavor to avoid sexist language are intellectual cowards; (3) that the notion that linguistic conventions reflect and reinforce the ways that we think-and indeed are the way that we think-is too arcane to "fathom" (and accordingly that law has a hegemonic function but language does not?); and (4) that to speak harshly of sexism and "to speak seriously of serious things" are mutually exclusive categories. 


\section{CONCLUSION}

If I am right about all of this, then the hostile reaction of many mainstream academics to the work of critical scholars is rich with irony: Whatever the possibilities may be in the current legal culture for the development of insights with genuine transformative potential, the What would you put in its place? obsession may render all of us considerably less likely to grasp, let alone to generate, them. As Kelman observes (at 290), liberal legalism's privileged positions reinforce a "utopian imagery of ordinary life" through the reproduction and maintenance of "a discourse in which we are repeatedly allowed to imagine a lovely world of self-determined subjects, expressing consistent, unambivalent, and unexceptionable desires, seeking their ends in a private world of voluntary transactions freed from force or nonnatural necessity by a state that imposes only clear rules against illicit force." When Kelman attempts to move that discourse to center stage and to call its continuing utility into question-to explore and expose "the gaps between the utopian fantasy and a shared, lived, complex reality" (id.) - he is taken to task for failing to offer a utopian fantasy of his own. Indeed, his critics posit one for him-assembled handily from liberal legalism's ready stock of counter-imagery-and then condemn him both for harboring Stalinist impulses and for denying that he does so. What would you put in its place? thinking thus operates as a highly effective inoculation against the twin viruses of self-consciousness and critique.

$$
* * * * *
$$

Make no mistake about the limits of my argument: I do not for a moment mean to minimize the contribution of willfulness and calculation in many of the past decade's just plain wrong-on-the-facts denunciations of scholars associated with $\mathrm{cls}^{74}$ I suspect, to take a not quite random example, that the editors of the Wall Street Journal who have displayed such a keen interest in the cls debate can, contrary to the available evidence, tell the difference between a Jaguar and a Nissan Sentra, even when they are reporting on Duncan Kennedy's driving habits. ${ }^{75}$ Indeed, Kennedy was

74. See, e.g., Jerry Frug, "McCarthyism and Critical Legal Studies," 22 Harv. C.R.-C.L. L Rev. 665 (1987) (book review). My own sense is that intergenerational jealousies, misunderstandings, and institutional power struggles account for even more of the hostile treatment of critical scholars than does the Red scare; Kelman offers a brief but insightful analysis along these latter lines (at 298-99 n.12).

75. I refer here to the op-ed piece run by the Joumal in 1990 by Brian Timmons, then a second-year student at Harvard. See Wall St. J., 3 Apr. 1990, at $\$$ A, p. 20. Timmons made a series of standard-issue anti-left charges against Kennedy-and leftist academics generally-that were intended to suggest that we all live lives of unremitting hypocrisy. Thus, he argued that we zealously support egalitarianism in every aspect of American life except with respect to the running of the elite educational institutions that give us our daily bread and that we broadly embrace the cause of working people in our scholarly work but shun them and ignore their interests in our personal lives. Drawing on a rhetorical move that has worked well for recent presidents and Supreme Court nominees alike-i.e., summon up a 
surely right when he argued several years ago that some cls detractors have deliberately engaged in what he called "the politics of mischaracterization." "76 But mischaracterization is as often the result of unexamined assumptions as it is of conscious manipulation, and the attacks on and misreadings of cls have sprung forth from too many quarters where good faith and good sense are otherwise the norm for me to be comfortable with only the latter story.

The point of this essay, then, is that What would you put in its place? thinking-together with the classic liberal division of the realm of the possible into dichotomous choices-has lead many critics of cls to conclude that the relentless exposure of liberalism's contradictions and the vigorous critique of its privileged positions is the product of covert political commitments. It is these assumptions that lead the critics, perhaps quite unconsciously, to project onto critical scholarship the very structures of thought that we are trying to understand and to rethink. And it is these assumptions that induce them to label $u s$ as the ones with the authoritarian impulse-and permit them to do so without the slightest trace of irony.

home-spun, folksy image just before you lie-Timmons invoked the populist wisdom of his working-class grandfather, with whom Timmons had reportedly discussed Kennedy's infamous proposal for job swapping between law faculty and custodial staff: "Few intellectuals, according to my grandfather, could ever speak for the common man, because few have ever lived his life. (I never told my grandfather about the Jaguar that Duncan Kennedy drives to school. I didn't have to.)" Id.

Jeremy Paul and I wrote a response pointing out that Timmons's charge was embarrassingly wide of the mark in Kennedy's case, citing among other things Duncan's outspoken support for aggressive affirmative action (indeed, randomness) in law school hiring and admissions policies, and his active personal involvement with housing and labor issues in the Harvard and greater Boston communities. Wall St. J., 7 May 1990, at $\$$ A, p. 15. Whether those facts undermined Timmons's broader claim may be a matter of opinion, but the Jour. nal edited out of our letter an additional point that might have called into question both Timmons's good faith and the Joumal's capacity for scrupulous fact checking when presented with assertions that correspond to its cozy world view: In 1990 Kennedy owned and drove a 1985 Nissan Sentra, not the Jaguar of Timmons's overactive imagination. The defensive circle-the-wagons response we later encountered when we asked Joumal officials either to correct the misreported fact or to print the censored portion of our letter revealed a commitment to "the party line"-on this, seemingly the most trivial of issues-that one would more readily associate with popular images of small-time dictators than with a respected organ of the national press; evidently, the perceived need to assure its readers that radicals drive fancy cars too (and hence can safely be ignored as hypocrites) outweighed the Journal's desire to get the facts straight.

76. The source of the quoted phrase is Kennedy's memorable extemporaneous response to Steven Burton's cls-believes-that-law-is-junk speech at the 1986 AALS annual meeting. For the published version of Burton's remarks, see "Reaffirming Legal Reasoning: The Challenge from the Left," $36 \mathrm{~J}$. Legal Educ. 358 (1986). 